УДК 005.1-043.86:005.7

DOI: https://doi.org/10.31866/2616-7573.2.2018.149297

КОВАЛЕНКО Слена Ярославівна,

кандидат економічних наук, доцент,

Національна академія керівних кадрів культури і мистецтв,

Київ, Україна, elena.kovalenko.ya@gmail.com

ORCID ID: https://orcid.org/0000-0003-2253-5762

\title{
ЕВОЛЮЦІЯ ТЕОРІЇ МЕНЕДЖМЕНТУ: ВІД БЮРОКРАТІї ДО АДХОКРАТІЇ
}

Анотація. Актуальність. Людство у третьому тисячолітті зіткнулося з глобальними змінами. Суперечливість, масштабність і складність цих змін, напруженість й нестабільність світового розвитку формують середовище, з яким старі організаційні структури вже не справляються, а популяризовані теорією нові структури ще не знайшли застосування на практиці. Як наслідок, відбувається гальмування процесів управління та стримування подальшого розвитку суспільства. Мета і методи. Мета статті - аналіз еволюції теорії менеджменту від бюрократії до адхократії в контексті розвитку цивілізації та обгрунтування оптимального типу організаційної структури життєдіяльності постіндустріального суспільства. Методологічною основою дослідження є діалектичний принцип пізнання, системний, еволюційний підходи до вивчення суспільних явищ і процесів та фундаментальні положення теорії менеджменту. Результати. Розкрито сутність понять бюрократичного й адхократичного управління. Досліджено еволюцію теорії менеджменту від бюрократії до адхократії в контексті розвитку цивілізації. Виявлено багатогранність феноменів бюрократії й адхократії та їх вплив на життєдіяльність суспільства. Доведено хибність теоретичних положень щодо можливості повної заміни бюрократії чистою адхократією. Обгрунтовано доцільність конгломератного типу організації. Висновки та обговорення. У XXI ст. не відбулося очікуваного краху бюрократії, а навпаки, спостерігається їі посилення на основі комп'ютерних технологій. Організація майбутнього - це структура конгломератного типу, що включає як основу збереження цілісності «легкий» ієрархічний каркас та набір децентралізованих ринкових й адхократичних робочих груп, занурених у зовнішнє середовище. Наукова новизна одержаних результатів полягає в узагальненні теоретичних положень щодо бюрократичних і адхократичних структур та у визначенні їх оптимального поєднання в побудові організацій постіндустріального суспільства, а практичне значення - у можливості використання цих ідей для проектування адаптивних організаційних структур в умовах глобалізації світу.

Ключові слова: теорія менеджменту, організація, організаційна структура, еволюція, бюрократія, адхократія, суспільство.

Коваленко Елена Ярославовна, кандидат экономических наук, доцент, Национальная академия руководящих кадров культуры и искусств, Киев, Украина 


\section{Эволюция теории менеджмента: от бюрократии к адхократии}

Аннотация. Актуальность. Человечество в третьем тысячелетии столкнулось с глобальными изменениями. Противоречивость, масштабность и сложность этих изменений, напряженность и нестабильность мирового развития формируют среду, с которой старые организационные структуры уже не справляются, а популяризованные теорией новые структуры еще не нашли применения на практике. Как следствие, происходит торможение процессов управления и сдерживание дальнейшего развития общества. Цель и методы. Цель статьи - анализ эволюции теории менеджмента от бюрократии к адхократии в контексте развития цивилизации и обоснования оптимального типа организационной структуры жизнедеятельности постиндустриального общества. Методологической основой исследования является диалектический принцип познания, системный, эволюционный подходы к изучению общественных явлений и процессов и фундаментальные положения теории менеджмента. Результаты. Раскрыта сущность понятий бюрократического и адхократического управления. Исследована эволюция теории менеджмента от бюрократии к адхократии в контексте развития цивилизации. Выявлена многогранность феноменов бюрократии и адхократии и их влияние на жизнедеятельность общества. Доказана ошибочность теоретических положений о возможности полной замены бюрократии чистой адхократией. Обоснована целесообразность конгломератного типа организации. Bыводы и обсуждение. В XXI в. не произошло ожидаемого краха бюрократии, а наоборот, наблюдается ее усиление на основе компьютерных технологий. Организация будущего - это структура конгломератного типа, которая включает как основу сохранения целостности «легкий» иерархический каркас и набор децентрализованных рыночных и адхократических рабочих групп, погруженных во внешнюю среду. Научная новизна полученных результатов заключается в обобщении теоретических положений относительно бюрократических и адхократических структур и в определении их оптимального сочетания в построении организаций постиндустриального общества, а практическое значение - в возможности использования этих идей для проектирования адаптивных организационных структур в условиях глобализации мира.

Ключевые слова: теория менеджмента, организация, организационная структура, эволюция, бюрократия, адхократия, общество.

Kovalenko Yelena, $\mathrm{PhD}$ (Economics), Associate Professor, National Academy of Managerial Staff of Culture and Arts, Kyiv, Ukraine

\section{Evolution of management theory: from bureaucracy to adhocracy}

Abstract. Actuality. Humanity in the third Millennium are faced with global changes. Inconsistency, the scale and complexity of these changes, tensions and instability, world development form the environment with which the old organizational structure can no longer cope, and popularized the theory of the new structure, it has not been yet found application in practice. As a consequence, the inhibition of the processes in governance and the deterrence of further development companies. Purpose and methods. The purpose of the article is to analyse the evolution of management theory from bureaucracy to adhocracy in the context of civilization development and study of optimal type in organizational 
structure of life in post-industrial society. Methodological basis of research is the dialectical principle of cognition, systemic, and evolutionary approaches to the study of social phenomena and processes, and fundamental principles of the theory of management. Results. The essence of the concepts of bureaucratic and adhocracy management. The evolution of management theory from bureaucracy to adhocracy in the context of the development of civilization. Revealed the diversity of the phenomena of bureaucracy and adhocracy and their influence on the activity of the society. Proved the fallacy of theoretical positions about the possibility of complete replacement of bureaucracy clean adhocracy. The expediency conglomerate-type organization. Conclusions and discussion. In XXI cent. did not happen to the expected collapse of the bureaucracy, and Vice versa, is increased on the basis of computer technologies. The organization of the future is the structure of the conglomerate of the type that includes a framework for the preservation of the integrity of the "easy" a hierarchical framework and a set of decentralized market and adhocracy working groups, immersed in an external environment. The scientific novelty of the obtained results is the generalization of theoretical propositions regarding the bureaucratic and adhocracy structures and in determining their optimal combination in building organizations of the post-industrial society, and the practical value - you can use these ideas for the design of adaptive organizational structures in a globalization world.

Keywords: theory of management, organization, organizational structure, evolution, bureaucracy, adhocracy, society.

\section{1. Актуальність проблеми Actuality of problem}

Перехід світової цивілізації до постіндустріальної ери та посилення глобалізації світу веде до кардинальних змін у життєдіяльності суспільства. Має місце як ускладнення взаємозв'язків і відносин, так і наростання дезорганізації, втрата стабільності, порядку, передбачуваності. Виникли і стали досить гострими проблеми, пов'язані з функціонуванням організацій, в яких відбувається життєдіяльність і які є основою існування людей.

Суспільство намагається подолати наростаючий вал проблем, запроваджуючи новітні інформаційні технології, вдосконалюючи нормативноправову та законодавчу базу. Проте всі ці та інші намагання ведуть не до спрощення і зменшення невизначеності, а до ще більшого ускладнення, посилення бюрократизації управління й інтенсивного розвитку негативного побічного продукту бюрократії - бюрократизму, який сьогодні паралізує творчість роботи вже не тільки в державному управлінні, але й управлінні бізнесом, культурою, наукою, освітою. I тому всі ці зусилля щодо налагодження функціонування організацій відповідно до нових умов життєдіяльності суспільства, при відсутності позитивних зрушень, породжують величезну хвилю незадоволення та критики. 
Передусім серйозні претензії до теорії менеджменту. А чи дає вона надійні «рецепти» щодо функціонування організацій в умовах постіндустріального суспільства? Багато питань щодо організаційних структур, зокрема бюрократичної: вона має право на існування чи ні? Якщо ні, то який новий тип структури? Якщо пропонується адхократія, то чому тоді цей тип структури не використовується повсюдно на практиці, як основа якої-небудь організації?

Стан вивчення проблеми. У науковій літературі радянського періоду, зважаючи на панування марксистського підходу до вивчення суспільних явищ, дослідження бюрократії обмежувалося переважно критикою іiі недоліків, незважаючи на реальне існування бюрократії як основної, універсальної форми організації суспільства в усіх соціалістичних і капіталістичних країнах світу (Блюмкин, 1987; Худокормов, 1988; Попов, 1989). Упродовж тривалого часу в нашій країні навіть слабкі натяки на можливість існування бюрократії як професійної групи, а тим більше як типу державного устрою вважалося неприпустимим. Відповідно до цього іiі аналіз здійснювався переважно у вигляді критики західних концепцій (Графский, 1981; Макаренко, 1985; Ожиганов, 1986; Хасбулатов, 1989). У пострадянський період, зі зміною соціальних процесів в Україні й інших республіках колишнього СРСР, спектр роздумів про бюрократію значно розширився. 3'явилися роботи, що аналізують феномени бюрократичної свідомості, зв'язок бюрократії з організаційно-управлінськими поняттями і явищами культури (Гайденко \& Давидов, 1991; Хасбулатов, 1991; Рудинський, 1994; Оболонский, 1996, 2011; Масловский, 1997; Яковенко, 2008; Батрименко, 2009; Туленков, 2011; Цапко, 2012; Боднарук, 2016; Паєтко \& Федосов, 2016; Мартинишин, 2018). А також стали доступними публікації зарубіжних учених, які досліджують проблеми не тільки бюрократії, а й інших форм організації життєдіяльності суспільства, зокрема адхократії (Камерон \& Куинн, 2001; Минцберг, 2004; Друкер, 2007). Однак в усіх цих і багатьох інших працях немає чітких, ясних відповідей на поставлені вище питання, що засвідчує певні проблеми теорії менеджменту стосовно організаційних структур нового суспільства.

Невирімені питання. Слід зазначити, що попри значний інтерес вчених до проблеми бюрократії та інших структур як основ організацій суспільства можна констатувати відсутність спеціального дослідження, в якому еволюція теорії менеджменту від бюрократії до адхократії поставала б об'єктом філософського, культурологічного й економічного осмислення. Втім, саме такий підхід до управлінської теорії може дозволити виявити багатогранність різних організаційних структур і міру їх впливу на життєдіяльність людей у реаліях індустріального та постіндустріального суспільства. 


\section{2. Мета і методи дослідження Purpose and methods of research}

Мета представленої статті полягає у здійсненні теоретичного аналізу еволюції наукових концепцій менеджменту організацій від бюрократії до адхократії, в контексті історичного розвитку суспільства від індустріалізму до постіндустріалізму й, на основі цього, обгрунтування найприйнятнішого нового типу організаційної структури.

Методологічною основою дослідження є діалектичний принцип пізнання, системний, цивілізаційний та еволюційний підходи до вивчення суспільних явищ і процесів, фундаментальні положення теорії структур та менеджменту організацій.

Для вирішення конкретних завдань використано історичний, діяльнісний, соціокультурний, компаративістський та інші методи, які дозволили дослідити багатогранні явища бюрократичного і адхократичного менеджменту в міжпредметних розрізах. Також застосовувалися такі загальнонаукові методи пізнання, як аналіз і синтез, індукція і дедукція, порівняння, узагальнення, формалізація, моделювання та прогнозування.

Інформаційною базою дослідження послужили наукові праці провідних вітчизняних і зарубіжних вчених, найзначиміші наукові концепції 3 приводу пояснення об'єкту дослідження.

\section{3. Результати дослідження Research results}

Усяка скільки-небудь значуща теорія виникає та розвивається в задоволення назрілих відповідних часу насущних соціальних потреб. I з'являється вона як відповідь людського інтелекту на це соціальне замовлення, висунуте з боку суспільства. Такою $є$ й теорія менеджменту організацій, яка впродовж останнього століття поступово еволюціонує від бюрократії до адхократії, враховуючи всі ті зміни, які відбуваються в організаціях, їх оточенні та суспільстві.

Б ю р о к р а т і я . Елементи бюрократії виникли з появою письма у Стародавньому Єгипті (IV тис. до н. е.), а далі, в поєднання з іншими організаційними структурами, поступово поширювалися на весь світ, сформувавшись зрештою у технічно унікальну форму організації життедіяльності суспільства (Коваленко, 2017, с. 59).

Бюрократична організація прийшла на зміну системі патріархальної, середньовічної адміністрації, за якої звичайній пересічній людині без грошей і зв'язків домогтися справедливості було практично неможливо: строків розгляду справ не існувало, порядок їх ведення і підвідомчість були вкрай невизначені й у всьому панували свавілля, особистий розсуд того, хто вирішує питання, що неодмінно супроводжувалося хабарами, 
вимаганнями та протекцією. Результат справи вирішували не правота людини, не об'єктивні обставини, а її статус, багатство, зв'язки, спритність, уміння задобрити потрібну особу (Мартинишин, 2018b, с. 88).

В італійському серіалі «Життя Леонардо да Вінчі» $є$ епізод про те, як цей великий мислитель і художник, один із небагатьох видатних геніїв людства, безуспішно намагався вирішити одну важливу для себе спадкову проблему, безпорадно блукаючи між столами клерків, які «відфутболюють» його від одного до іншого. Ця сцена може слугувати виразною характеристикою патріархальної системи управління, в якій людина повністю беззахисна перед свавіллям осіб, які на свій розсуд вирішують життєво важливі для неї питання.

Втім, заради справедливості скажемо, що патріархальна система мала і свої зручності, оскільки, знайшовши з «потрібною особою» належний контакт, прохач міг без формальної тяганини (а часто - i всупереч закону) вирішити свою справу, і між ними виникали не холодні ділові, а теплі, деколи навіть дружні стосунки. Але, зрозуміло, недоліки такої системи організації управління явно переважували.

I ось як альтернатива їй прийшла інша форма вирішення справ бюрократична, якій (в ідеалі) властиві їх ведення компетентними і безпристрасними виконавцями у повній відповідності до законодавства та процедури, упорядкованість діловодства, свобода від суб'єктивних впливів. Така організація припускає панування загальнообов'язкових регламентованих процедур, виконання яких не залежить від того, хто саме і стосовно кого вони виконуються. Усі рівні перед єдиним порядком. Уніфікація стає гарантією проти недоліків конкретних людей і можливих зловживань. Так коротко можна описати суть бюрократії.

Термін «бюрократія» був уведений французьким економістом Венсаном де Гурне в 1745 р., який під бюрократією мав на увазі уряд, в якому міністерські пости обіймали професійні чиновники, які сліпо або формально наслідували правила, не проявляючи турботи про інтереси справи (Цит. за: Тюрго, 2010, с. 73). Тобто в момент свого утворення слово «бюрократія» мало вже зневажливе значення. У буквальному розумінні воно означає «владу стола чиновника», або «владу столоначальника» (від фр.

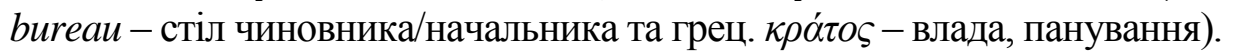

Наукове осмислення феномену бюрократії почалося у XVIII ст. в епоху підйому Індустріалізму, виникнення Свропейської раціональної науки та появи Ньютонівської механістичної картини світобачення. У цих умовах відбувається формування теорії бюрократичної організації, в рамках якої основна увага приділяється раціональному, безособовому управлінню на засадах чіткого визначення правил.

У своїх витоках дослідження бюрократії оформилося у два напрями: політичний і соціологічний аналіз бюрократії. 
Перший напрям аналізу зосереджує увагу на вивченні бюрократії як політичної основи правління й оперує масштабними категоріями, такими як держава і суспільство, класи і маси. Бюрократія у ньому ототожнюється з державою. У число засновників цього напряму, незважаючи на великі відмінності в теоретичних побудовах, включені насамперед такі видатні німецькі вчені, як Г. Гегель і К. Маркс.

Початок розвитку теорії бюрократії на терені політичного аналізу поклав Георг Гегель у своїй праці «Філософія права» (1821р.). Основою його концепції $є$ положення про те, що завдання бюрократії - служіння суспільним інтересам, сенс якого полягає у збереженні єдності країни, іiі стабільності та стійкості. Практичними виконавцями об'єднувальної функції держави стає прошарок чиновників, службовців, функціонерів, які у процесі уніфікації й раціоналізації суспільного організму протистоять роздробленості, багатоликості та мозаїчності суспільства. Сенс існування цього прошарку і його завдання полягають у відстоюванні і збереженні ідеї первинності суспільства як найважливішої соціальної цілісності.

У часи Г. Гегеля бюрократія асоціювалася насамперед із поняттям централізованої держави як прогресивного для тієї епохи явища. Він бачив у раціональному устрої держави ідеал улаштування людського суспільства як з точки зору найефективнішого способу досягнення загального блага, так і в плані реалізації індивідуальних цілей самореалізації особистості (Гегель, 1990).

Наступником гегелівської традиції нерідко вважають Карла Маркса. Однак його погляд на сенс і цілі бюрократії в суспільстві радикально протилежний гегелівським переконанням. К. Маркс у своїй праці «До критики гегелівської філософії права», написаній у 1843 р., представляє бюрократію як абсолютне зло. Він бачить у ній насамперед політично активний клас, безпосередньо пов'язаний з управлінням державою.

Найціннішим у позиції К. Маркса є те, що він виявив відчуження бюрократичного прошарку від суспільства. Його відокремленість не $\epsilon$ простою невинною самоізоляцією. Сутність останньої має політичний характер із багатьма згубними наслідками як для суспільства, так і для самої держави. I безсумнівна заслуга Маркса полягає в тому, що він детально досліджує й висвітлює ці наслідки. Зокрема, він поставив у провину бюрократії заміщення загального суспільного інтересу своїм вузькокорисним інтересом, який вона видає за загальносуспільний. У такий спосіб відбувається «присвоєння держави» армією чиновників, тоді як у дійсності чиновництво органічно нездатне вирішувати державні проблеми. Таким чином, бюрократія, витісняючи справжні і насущні державні завдання, утворює «жахливий організм-паразит, який обвиває наче сіткою усе тіло» (Маркс, 1974, с. 298) суспільства.

Бюрократія в інтерпретації К. Маркса - це передусім царство некомпетентності. Він пише: «Верхи покладаються на низи в усьому, що 
стосується знання подробиць; низи ж довіряють верхам у всьому, що стосується розуміння загального, $\mathrm{i}$, таким чином, вони взаємно вводять один одного в оману» (Маркс, 1974, с. 299).

Приписуючи такі відхилення в діяльності організацій виключно капіталістичній формі суспільного устрою, К. Маркс доводить, що вони $\epsilon$ результатом розвитку тенденції відчуження адміністративного апарату від суспільства й реальних потреб індивідів. Управління перетворюється на самоціль, на інститут із власним внутрішнім життям, незбагненним для непосвячених. Коло людей, які займаються управлінням, стає замкнутою кастою, що охороняє свої секрети, які сприяють їх виживанню як привілейованого прошарку суспільства.

Засновником другого - соціологічного - напряму дослідження феномену бюрократії вважається німецький соціолог Макс Вебер, який першим продемонстрував достоїнство бюрократії як системи управління. Його основні ідеї про бюрократію викладені у книзі «Господарство та суспільство» (1921р.).

На думку М. Вебера, тенденцією всесвітньо-історичного процесу $\epsilon$ раціоналізація соціальної дії, яка може бути визначена на основі формального раціоналізму - вибору засобів досягнення цілей за допомогою встановлених правил. Результатом процесу раціоналізації є виникнення бюрократії (Вебер, 2010, с. 92).

Вебер обгрунтував тезу про те, що продуктом західної цивілізації був формальний раціоналізм, який посів у ній домінуюче місце. Вступивши на шлях раціоналізації, Європа вже не зможе з нього звернути, адже раціоналізуються усі сфери життя суспільства. Він підкреслював, що бюрократія $\epsilon$ технічно найбільш ефективним типом організації. На його думку, саме технічна перевага бюрократії зумовила її поширення: «Точність, швидкість, однозначність, знання справи, послідовність, такт, єдність, сувора субординація, зменшення тертя, витрат матеріальних i людських ресурсів - усе це набуває максимального розвитку в бюрократичній системі» (Вебер, 2010, с. 188).

У теорії Вебера організація є стабільною, закритою, жорсткою системою, що відповідає стадії машинного виробництва. Організації володіють єдиним набором цілей, які вказують основний напрямок діяльності і транслюються у різні підцілі, що підлягають досягненню. Бюрократія як форма управління відповідає саме такій організації. Тобто мислитель порівнював бюрократію з машиною, а решта форм (харизматична, традиційна та ін.) розглядалися ним як відповідні немеханізованим методам виробництва.

Бюрократія, на його думку, є ефективною «людською машиною» управління. Причина ефективності полягає у використанні засобів, які найкращим чином ведуть до поставленої мети, при цьому вони не схильні до суб’єктивізму керівника або впливу традицій. 
Раціональність бюрократичної організації виявляється в можливості передбачити наслідки своїх дій. Контроль за діями здійснюється за допомогою особливої системи правил та ієрархії влади. Таким чином, бюрократію можна розглядати як кінцеву стадію деперсоналізації влади, що і є головним досягненням бюрократичних моделей.

На думку М. Вебера, бюрократична організація прогнозує досить передбачуване і стабільне середовище, для якого характерна наявність раціональних структур. Ці структури «населяють» «раціональні індивіди», які беззаперечно виконують розпорядження і відповідають запропонованим їм ролям (Вебер, 2010, с. 189).

Організації бюрократичного типу використовують адміністративні методи управління і мають чітку вертикальну ієрархію. Вони відрізняються суворою спеціалізацією, наявністю штатних чиновників, а для працівників характерна націленість на кар'єрне зростання.

Головною ланкою у бюрократичних організаціях є різні бюро, служби, які спеціалізуються на виконанні управлінських функцій, що залишаються незмінними й не залежать від переміщення і думок окремих працівників цих підрозділів. Управлінська робота грунтується на письмових документах.

Згідно з теорією Вебера, бюрократична адміністрація і службовці повинні відповідати таким критеріям (Вебер, 2010, с. 189-190):

- службовці підкоряються владі в силу безособових обов'язків;

- службовці утворюють ясно виражену ієрархію посад;

- кожна посада має чітко виражену сферу компетенції;

- заняття посад відбувається на контрактній основі;

- кандидати на посаду відбираються на основі їх кваліфікації;

- шкала окладів приблизно відповідає рівням ієрархії;

- виконання посадових обов'язків - основне заняття службовця;

- просування визначається старшинством або рівнем досягнень;

- службовець не є власником і посада не $є$ його власністю;

- поведінка службовця повинна відповідати існуючим вимогам.

На думку М. Вебера, жодні відступи від формально встановлених процедур і правил неприпустимі. Неформальні відносини в організації не можуть позитивно впливати на її результати. Тобто у його теорії були відсутні особистісні засади в міжособистісних стосунках.

Отже, основними характеристиками бюрократичної організації є:

1) розчленування діяльності організації на окремі операції і суворе визначення відповідальності за їх виконання та повноважень працівників;

2) формування ієрархічної структури організації, що складається з ланцюга посад і команд;

3) наявність системи безособових правил, що регулюють порядок роботи й відповідальність кожного члена організації; 
4) безособовість керівника, який керує на основі раціональних стандартів, що виключають вплив особистої думки та емоцій;

5) відповідність кваліфікації працівників займаній посаді, кар'єрне просування на основі кваліфікаційних вимог, оплата праці залежно від категорії та стажу;

6) наявність системи контролю і санкцій за невиконання службових обов'язків;

7) захист працівників від довільного звільнення або пониження, що зміцнює їх відданість організації, формує корпоративний дух.

Характеристики бюрократичної організації, розглянуті Вебером, дозволили виділити напрямки формалізації іiі діяльності, а бюрократична система управління дозволяє вирішувати проблеми постійного ускладнення виконуваних завдань.

Основний внесок М. Вебера у розвиток науки управління полягає в розробці теорії раціоналізації і бюрократичної побудови організацій. Представники механістичного напрямку в менеджменті, передусім $\Phi$. Тейлор, А. Файоль та М. Вебер, хоча й по-різному інтерпретували ключові поняття і принципи організації, проте були породженням однієї історичної епохи. Тому вони шукали способи підвищення ефективності функціонування організацій, підвищення продуктивності як управлінської, так і виконавської праці. На відміну від Ф. Тейлора, який прагнув до раціоналізації праці робітника, А. Файоль - адміністрації, М. Вебер створив теорію раціоналізації організації в цілому. Він намагався знайти способи і методи такої організації управління, при якій вся організація працювала б як машина.

Сьогодні багато вчених і практиків управління вважають, що виділені М. Вебером риси раціональної моделі бюрократії насправді набули протилежних характеристик. У класичній раціональній моделі бюрократії рішення і дії посадових осіб у формально встановленій системі правил та інструкцій повинні вести до ефективної, безперебійної діяльності бюрократичного апарату. Однак на практиці це беззастережне слідування правилам і фіксованим процедурам часто призводить до перетворення формальних процедур на свого роду фетиш, на абсолютне правило, коли формалізм у бюрократії стає самоціллю, а інструкція із засобу для досягнення мети перетворюється на ціль у собі.

3 дослідженням цих та інших дисфункцій бюрократії, виявленням непередбачених реакцій членів організації, аналізом тенденцій розвитку бюрократичної системи пов'язана поява різноманітних концепцій бюрократії. Не заперечуючи М. Вебера в тому, що бюрократія більш ефективна, ніж альтернативні форми організації, багато дослідників підкреслювали також істотний характер іiї негативних наслідків.

Американський соціолог Роберт Мертон в одній зі своїх перших робіт, присвячених проблемі бюрократії - «Бюрократична структура й 
індивідуальність» (1940р.), - доводив, що в сучасному світі, незважаючи на ряд позитивних досягнень і функцій бюрократичної організації (захист підлеглого від довільної поведінки керівництва, полегшення взаємодії посадових осіб незалежно від їх неформальних відносин, об'єктивність й обмеження імпульсивності поведінки, технічна ефективність, повне усунення неофіційних відносин, нераціональних ідей і т. п.), бюрократія усе більше проявляє свою недосконалість, що підтверджується навіть фактом перетворення слова «бюрократ» на лайливе (Мертон, 2006, с. 323).

На його думку, ідеальний тип бюрократії, проголошений Вебером, володів дуже характерною рисою - стримуючою дисфункціональністю. Саме ця риса бюрократії заважає їй бути оптимально ефективною.

При вивченні негативних сторін бюрократії Р. Мертон опирався на концепції трьох вчених: концепцію «навченої нездатності» Т. Веблена; концепцію «професійного психозу» Дж. Дьюї; концепцію «професійної деформації» Т. Уорнотта. Навчена нездатність відноситься до тієї сфери, в якій здібності використовуються не за призначенням або просто нікому не потрібні, а неадекватна гнучкість у застосуванні навичок у мінливій обстановці призводить до серйозних неузгоджень. Професійний психоз і деформація означають, що в результаті щоденної рутини розвиваються особливі вподобання, антипатії та акценти.

До недоліків бюрократичних організацій Р. Мертон відносить:

По-перше, зміщення акценту від мети до засобів, що викликане величезною символічною значимістю правил і норм. На його думку, бюрократична структура чинить постійний тиск на посадову особу, щоб вона стала методичною, розсудливою, дисциплінованою. Звідси - першочергове значення дисципліни, яка може бути ефективною тільки тоді, коли ідеальні схеми підкріплені сильними почуттями, що тягнуть за собою відданість обов'язкам, гостре відчуття обмеженості повноважень, компетентності та методичне виконання рутинної роботи.

Однак, як підкреслює Р. Мертон, для забезпечення дисципліни ці почуття часто бувають інтенсивнішими, ніж необхідно. У результаті відбувається перенесення почуттів із цілей організації на окремі деталі поведінки, що вимагаються правилами. Прихильність нормам і правилам, спочатку задуманим як засіб для досягнення певного результату, поступово перетворюється на самоціль: відбувається процес підміни цілей, засіб стає метою. Виникає ситуація, при якій інструментальний і формальний аспекти бюрократичної посади вважаються більш важливими, ніж сам зміст роботи. Дисципліна як дотримання інструкцій вже не сприймається тільки як засіб, розроблений для досягнення цілей, а стає необхідною цінністю в житті чиновника (Мертон, 2006, с. 327).

Результатами зміщення вихідних цілей є: відсутність гнучкості в організації; втрата здатності пристосовуватися до ситуації; формалізм і 
ритуалізм поведінки, викликаний дотриманням процедур; виникнення феномену техніцизму, або бюрократичної тяганини.

Таким чином, первинна необхідність відповідати правилам стає перешкодою для досягнення цілей організації.

По-друге, захист чиновниками своїх групових інтересів, а не своєї клієнтури й обраних вищих представників. На думку Р. Мертона, всі чиновники, які працюють разом, мають почуття загального призначення. У них однакові інтереси, особливо відтоді, як кар'єрне просування стало за принципом старшинства. Закріплені законом права чиновника протистоять будь-якому новому порядку. Чиновники стають емоційно залежними від бюрократичних символів і статусів, вони пишаються своїм умінням чинити опір змінам, які їм нав'язуються. У результаті багато бюрократичних норм, спочатку введених із технічних причин, стають жорсткими та священними (Мертон, 2006, с. 332).

По-третє, знеособлювання відносин, яке стає причиною конфліктів. Як реакція у відповідь на виникнення конфлікту та протести клієнтів бюрократ захищає себе, діючи ще більш формальним чином. Прагнення до мінімізації особистісних відносин призводить до знеособленого підходу до розгляду справ, зростання «зарозумілості» та «зверхності», домінування функціональних відносин замість людських.

Крім того, особа, наділена владними повноваженнями, часто поводиться як представник величі всієї організації, незалежно від ії посади в бюрократичній ієрархії. Особливо чітко це проявляється на рівні державних організацій, де напруженість зростає через невідповідність ідеології та реальності: урядові службовці покликані бути «слугами народу», а фактично вони часто перебувають у вищому статусі.

Знеособленість, стереотипність, категоричність поведінки керівників зрештою призводить до рутинності процесу прийняття рішень, що значно знижує потребу в пошуку нових альтернатив.

У цілому, розглядаючи особливості бюрократичних організацій із позицій функціонального підходу, Р. Мертон дійшов висновку, що один i той самий структурний елемент може мати як функціональні з точки зору досягнення організаційних цілей наслідки, наприклад передбачуваність, так і дисфункціональні - відсталість і нездатність швидко пристосовуватися до зміни ситуації, формалізм та ритуалізм (Мертон, 2006, с. 336).

Ідея дисфункціональності бюрократії, висунута Р. Мертоном, була підхоплена в наступних емпіричних дослідженнях і розвивалася у політичній полеміці, управлінській теорії та соціології.

У 50-х pp. ХХ ст. американський соціолог Елвін Гоулднер при розробці своєї теорії бюрократії, викладеній у книзі «Моделі індустріальної бюрократії» (1954р.), виходив з того, що зміна цього інституту відбувається паралельно з розвитком суспільства. На його думку, сучасне суспільство 
переживає вплив досягнень третьої революції - комунікативної, суттю якої $є$ зміни в баченні. Виникнення мас-медіа і масове виробництво недорогих продуктів культури викликали якісні зрушення в усіх сферах соціокультурного життя, здійснили революцію в політичній системі, підштовхуючи ії до реалізації ідеалів прямої демократії та зародження індустрії свідомості (Gouldner, 1954, p. 29).

Внутрішня причина кризи західної культури та науки - закладена в них «модель непрямого правління» буржуазії, яка поступово передала низку своїх функцій, насамперед із виробництва свідомості, бюрократії, ставлячи себе у все більшу залежність від неї. При цьому знеособлені бюрократичні структури прагнуть до штучної підтримки рівноваги в суспільстві, наслідком чого є блокування будь-яких імпульсів до зміни.

У цих умовах, на думку Е. Гоулднера, бюрократична організація сама зазнає паралельної еволюції від авторитарної до представницької (Gouldner, 1954, p. 43-47).

Авторитарна (репресивна) бюрократія заснована на наказах і вимозі сліпого виконання установлених правил. Вона базується на суворому підпорядкуванні ієрархії та страху покарання і не має стимулів до власної автономної активності. Цей тип бюрократії виникає тоді, коли в організації, у результаті різних дисфункцій, покора перетворюється на самоціль, а влада узаконюється самим фактом перебування на посаді.

Представницька (експертна) бюрократія спирається на знання та вміння і заснована на прагненні переконати у правильності вимог та доцільності їх виконання. Для такого типу бюрократії характерна влада, яка грунтується на принципах професіоналізму, відповідальності перед справою, корпоративному співробітництві.

Представницька бюрократія стала втіленням технічного розуму, технічної раціональності й ефективності. Але вона також небезпечна, оскільки претендує на монополію виробництва бачення світу, деморалізує активність людей фактологічною прозаїчністю. Технократії, що зуміла потіснити правлячі еліти, може протистояти соціогуманітарна інтелігенція як новий клас, що володіє культурним капіталом.

При розробці своєї теорії Е. Гоулднер виходив із відмінності двох понять - «бюрократія» і «бюрократизм» (Gouldner, 1954, p. 114-116).

Бюрократія $\epsilon$ нормальним і здоровим організаційним інститутом. Позитивною рисою бюрократичної моделі організації $\epsilon$ те, що бюрократичні правила істотно знижують напруженість у робочих групах і підвищують здатність системи до забезпечення рівноваги та інтеграції.

Бюрократизм - це негативні прояви бюрократичної практики. Він характеризується як дисфункція, патологія, основа появи напруженості та конфлікту в організації. Його рисами є відсталість, формалізм і тяганина, що виникають у результаті зростання самоцінності формальних правил 
і норм. Із бюрократизмом пов'язане поняття «бюрократичний саботаж» дії бюрократії, що перешкоджають нормативному функціонуванню організації з метою збереження власного місця.

Як і Р. Мертон, Е. Гоулднер розглядав наслідки застосування бюрократичних правил для підтримання організаційної структури. На його думку, контроль, виконуючи функції збереження, підтримання стабільності та рівноваги частин організації, часто призводить до порушення рівноваги організації в цілому.

Е. Гоулднер виділив дві моделі організації, що описують її двоїсту сутність: природну та раціонально-штучну (Gouldner, 1954, p. 241).

У природній моделі організації акцент робиться на стихійних процесах, а організація розглядається як соціальний організм, який еволюційно і поетапно розвивається та функціонує за своїми законами. Її центральною проблемою, як і біологічних організмів, $\epsilon$ виживання.

В раціонально-штучній моделі організації увага акцентується на запланованих і спроектованих процесах. Сама організація трактується як свідомо проектована відповідно до мети штучна система, що формується для досягнення певних цілей та вирішення завдань.

На цій основі Е. Гоулднер спробував проаналізувати природу конфліктів, напруженості, суперечностей у логіці кар'єри управлінця. Він висунув тезу про те, що організація прагне до існування навіть після досягнення поставлених цілей і до асиметричної взаємозалежності іiі частин (Gouldner, 1954, p. 258).

Значний внесок у розвиток теорії бюрократії здійснив також Ентоні Доунс - американський фахівець у галузі економічної теорії бюрократії. Його праця «Всередині бюрократії» (1967р.) була присвячена розгляду внутрішніх процесів, механізмів і життєвого циклу бюрократії, проблемам організаційного спотворення інформації та комунікацій.

Найбільший вплив на наступних розробників теорії бюрократії зробила концепція життєвого циклу бюрократичних структур. Ця концепція описує процес створення і розвитку бюрократичних організацій, виділяє етапи бюрократичного зростання та стагнації, так само як і їхній вплив на управлінську діяльність.

Е. Доунс (Downs, 1967, p. 42) підкреслював, що для новоствореної бюрократичної структури дуже важливо забезпечити зовнішню підтримку, для цього вона повинна постійно демонструвати необхідність своїх послуг іншим організаціям, які мають життєво важливі для неї ресурси. Існування нових бюрократичних структур, на думку автора, схильне до великого ризику, оскільки спочатку зовнішні джерела їх підтримки дуже слабкі, розрізнені і не мають чітко відрегульованих відносин із бюро. Крім того, поділ праці в суспільстві приводить до того, що будь-які потреби можуть бути задоволені іншими структурами. Виходячи з цього, 
він вважав, що критичним моментом початкового етапу бюрократичної організації є досягнення організаційної автономії, під якою розумів певний ступінь володіння організацією власною сферою компетенції, чітко окресленим колом клієнтів і незаперечною правоздатністю в галузі деяких функцій.

Взаємодія внутрішніх і зовнішніх чинників створює певні кумулятивні ефекти зростання та спаду в життєвому циклі бюрократичних структур. До факторів їхнього зростання Е. Доунс відносив (Downs, 1967, p. 63):

- збільшення значення в суспільстві виконуваних організацією соціальних функцій;

- надання організацією, що перебуває на стадії зростання, своїм співробітникам великих можливостей у розвитку кар'єри;

- створення нових управлінських посад, на які залучаються нові співробітники, зацікавлені у швидкому просуванні по службі;

- скорочення консервативно налаштованих співробітників, які не здатні працювати в ситуаціях із високим рівнем невизначеності, постійними змінами і важкою щоденною працею;

- зміцнення переважаючого положення кар'єристів (у тому числі й на керівних посадах);

- активне застосування інноваційних методів і технологій для розвитку нових напрямків діяльності.

Таким чином, бюрократична структура прагне стати і стає усе більш здатною використовувати інноваційні методи і розширювати коло соціальних функцій, створюючи нові та перехоплюючи старі в інших, менш динамічних організацій. Нарощування функцій веде до кумулятивних змін характеру персоналу, що визначає подальше зростання організації.

Е. Доунс відзначав, що в міру зростання організація зустрічається iз серйозними перешкодами. Вони такі (Downs, 1967, p. 65):

- посилення протиборства з іншими організаціями;

- наростання ворожості функціональних конкурентів;

- труднощі у плануванні та координації;

- конфлікти між кар'єристами.

Зрештою ці чинники сповільнюють зростання і розвиток бюро й можуть навіть зовсім зупинити цей процес.

У будь-який момент, коли темпи зростання бюро стають нижчими за середні темпи зростання інших організацій, якісний склад його персоналу може змінитися у напрямку прямо протилежному, що існував у період дії ефекту зростання. Всі ці процеси зрушують співвідношення консерваторів і кар'єристів на користь перших. У результаті внутрішня політика бюро стане більш консервативною, можливості інноваційного розвитку і розширення кола функцій значно зменшаться. Проте, на думку Доунса, ефект спаду не зовсім симетричний ефекту зростання.

Далі Е. Доунс зазначає, що бюрократичній структурі спочатку властива тенденція до розширення, незалежно від того, $є$ чи немає реаль- 
ної необхідності у збільшенні кількості наданих нею послуг. При цьому, як правило, обмежень для їх укрупнення стає менше, і ці обмеження спрацьовують менш автоматично.

На думку Е. Доунса, основні причини того, чому бюро прагнуть до розширення, наступні (Downs, 1967, p. 89-91):

1) укрупнення майже будь-якої організації надає її керівникам більше влади, грошей і підвищує їх статус, у результаті чого вони свідомо підтримують зростання організаційних структур;

2) укрупнення скорочує вірогідність внутрішніх конфліктів, оскільки організація зможе надавати деяким або навіть кожному можливість підвищення свого статусу без необхідності одночасного зниження статусу інших осіб. Отже, керівникам просто необхідно стежити за тим, щоб організація росла, з метою підвищення морального рівня і зменшення числа конфліктів;

3) збільшення розмірів організації може також поліпшити показники її продуктивності та шанси на виживання. Великі організації мають більше шансів на виживання, ніж невеликі, оскільки можуть домогтися економії через посилення спеціалізації, здатні надавати сильніший опір несприятливим чинникам навколишнього середовища, мають можливість витрачати більше коштів на розвиток, нові технології.

Е. Доунс одним із перших в управлінській науці поставив проблему віку організації (Downs, 1967, p. 114). На його думку, бюрократичні структури, як і люди, з віком змінюються цілком передбачувано. По-перше, із накопиченням досвіду вони краще виконують доручені їм функції. По-друге, з віком багато бюрократичних структур прагнуть розвинути все дедалі більше формальну систему правил поведінки для всіх можливих ситуацій.

Бажання закріпити набутий досвід змушує чиновників організації розробляти більш докладні правила. Вони, з одного боку, помітно покращують здатність бюрократичної структури успішно справлятися із ситуацією, з якою вона раніше вже стикалася, і роблять поведінку якихось відділів організації більш стабільною і передбачуваною. Однак, з іншого боку, ці правила відволікають увагу керівників від соціальних функцій організації, змушуючи їх стежити за їх неухильним виконанням i сприяють ускладненню структури, збільшуючи іiі інертність.

Звідси Е. Доунс доходить висновку, що старі бюрократичні структури стійкіші, але менш гнучкі, ніж молоді (Downs, 1967, p. 116). У міру старіння організації і правила поведінки, і система управління ускладнюються. Керівники ж прагнуть змінити початкові цілі ії існування, для того щоб продовжити життя організації та зростання іiі управлінських структур. Ця зміна акцентів полягає у гарантуванні кар'єрного росту керівникам організації. Тому кількість керівників у старіючій організації збільшується. 
На цій основі Е. Доунс виявив закон посилення консерватизму: всі організації з віком стають консервативнішими, якщо не перебувають на стадії швидкого зростання або внутрішньої реорганізації (Downs, 1967, p. 214). 3 цього закону, а також з інших вікових закономірностей він зробив такі висновки: чим старша бюрократична структура, тим більше у неї шансів на виживання; чим старша бюрократична структура, тим більше коло вирішуваних нею соціальних завдань.

Один із ефектів старіння бюрократичної структури, за Е. Доунсом, полягає в тенденції збільшення середнього віку її співробітників. На його думку, незабаром після періоду швидкого підйому зростання сповільнюється, і бюрократична структура входить у стадію стагнації. В організації формується ядро, яке має приблизно однаковий вік. Це тягне за собою такі наслідки (Downs, 1967, p. 251):

- існують проблеми з підвищенням по службі для співробітників старшої вікової групи, оскільки багато хто з них отримали необхідну кваліфікацію одночасно;

- великий відсоток працівників організації перетворюється на консерваторів через солідність віку і неможливість продовжувати просування по службових щаблях;

- найбільш кваліфіковані працівники покидають організацію, оскільки їм надається більше можливостей в інших місцях, тому бюрократична структура стає притулком «середнячків».

Бюро пройде стадію кризи виживання, коли ядро підійде впритул до віку виходу на пенсію. Раптово звільняться багато вакансій у вищих ешелонах управління.

На думку Е. Доунса, здатність бюрократичних структур продовжувати функціонування після того, як їх реальна корисність уже вичерпана, $\epsilon$ однією із тих їх властивостей, які надають цим структурам якийсь міфологічний відтінок (Downs, 1967, p. 260). Причини, за якими бюрократичні структури - особливо у сфері державного управління - досить рідко припиняють своє існування після успішного подолання початкового порогу виживання, такі: видозміна своїх функцій; вплив так званих «завзятих клієнтів», наприклад, у галузі оборонної промисловості; менша, ніж у приватних комерційних фірм, схильність до відкритих конфліктів між собою (таким чином, менша ймовірність взаємознищення).

Наприкінці Е. Доунс робить висновок, що, незважаючи на низький рівень смертності, бюрократичні організації рідко продовжують існування протягом такого тривалого періоду часу, як, наприклад, століття (Downs, 1967, p. 281). Як правило, організації не переживають те соціокультурне середовище, у рамках якого вони створювалися і розвивалися. Найстійкіші в цьому сенсі структури - церква та університети. 
Помітний вплив на розвиток теорії бюрократії та її осучаснення здійснив французький соціолог Мімель Крозьє. Його головні ідеї викладені у працях «Бюрократичний феномен» (1963 р.), «Актори та системи» (1977 р.), «Занепокоєння про Америку» (1980р.).

Увага М. Крозьє до проблеми бюрократизації багато в чому була продиктована тим, що, на його думку, головною причиною кризи суспільства $є$ бюрократична криза. Він вважав, що, незважаючи на тривалу й досить пильну увагу до цієї теми, проблема бюрократії досі не отримала належного вирішення і тому залишається ідеологічним міфом нашого часу. Цей парадокс, на думку дослідника, пов'язаний із подвійністю явища бюрократії. 3 одного боку, розвиток бюрократичних процесів $\epsilon$ наслідком і проявом раціональності, в силу чого бюрократія справді стає найдосконалішою формою організаційної реальності. 3 іншого боку, організації такого типу досягають успіху завдяки своїм поганим якостям, тобто зведенням своїх членів до ситуації стандартизації. За образним висловом М. Крозьє, бюрократія виступає «як свого роду Левіафан, який готується навернути в рабство всю людську расу» (Grozier, 1963, p. 31).

На думку М. Крозьє, веберівська модель, яка становить безсумнівну основу управлінських наук XX ст., потребує доповнення та осучаснення. 3 наукової точки зору феномен бюрократії характеризується чотирма основними особливостями (Grozier, 1963, p. 36-37):

1) прийняття рішень здійснюється централізовано і штучним чином ізольовано від їх здійснення: ті, хто приймає рішення, не займаються їх безпосередньою реалізацією; ті, хто знаходяться на нижніх щаблях ієрархії, не приймають рішень і не виявляють до цього інтересу, але зате набувають досвіду реалізації чужих рішень. Така соціальна і функціональна дистанція між двома групами дозволяє кожній із них захищатися від впливів іншої;

2) широке застосування мають універсальні та знеособлені правила. Відсутні можливості для вирішення приватних і дискреційних проблем. Загальні принципи і стандартні процедури охоплюють всі ситуації, завдання та проблеми. Сформовані правила дають учасникам можливість поступово створювати свої автономні ніші;

3) сильний тиск із боку груп із рівними повноваженнями має на увазі, що кожен ієрархічний рівень $є$ значною мірою ізольованим від інших, і всередині організації існує глибока соціальна стратифікація. Пристосовуючись до інтересів своєї групи, індивіди можуть знизити ступінь своєї залежності від вищого керівництва;

4) в умовах жорстких структур і низьких комунікативних можливостей владні зв'язки між різними ієрархічними рівнями та групами розвиваються паралельним і неформальним способом. Процеси обміну інформацією між «верхом» і «низом» здійснюються за посередництва профспілок.

Згідно з підходом М. Крозьє, організації і процеси бюрократизації, що в них протікають, несуть на собі відбиток національних особливостей 
і тому є культурним феноменом, якому притаманні специфічні норми та цінності (Grozier, 1963, p. 44). Соціолог показує, що, наприклад, у Франції бюрократичні організації демонструють такі зразки поведінки, як боязнь прямих відносин без посередників і прагнення до формальної рівності між членами одного ієрархічного рівня.

Для пояснення причин порушення оптимального функціонування бюрократичної організації і виникнення дисфункцій М. Крозьє використовує поняття «дискреційної влади» (Grozier, 1963, p. 79). Він вважає, що в будь-якій організації є зони невизначеності для здійснення формальної влади. Джерелами невизначеності є такі сфери або зони діяльності в організацій, де обмежена можливість суцільного регламентування або іiі немає зовсім. У такій ситуації виникає можливість по-своєму інтерпретувати власну поведінку. Члени організації починають використовувати цю невизначеність для реалізації власних корисливих інтересів: або заради влади над іншими, або для набуття особистої свободи та незалежності.

До зон невизначеності М. Крозьє відносить: експертне знання і вміння; відносини організації із зовнішнім середовищем; контроль над комунікаційною мережею та інформацією; наявність загальних правил і право керівництва їх встановлювати (Grozier, 1963, p. 84-86).

Влада одного актора (будь-якого працівника або менеджера) над іншими залежить від його ресурсів і, відповідно, від контролю над джерелами невизначеності. Залежно від значимості для функціонування організації конкретної невизначеності, контрольованої конкретним актором, зростає і його влада. За умови правильного використання джерела невизначеності навіть слабкий може виявитися володарем більшої влади, якщо він поставить сильного в таку ситуацію, в якій останній не зможе використовувати свою силу.

М. Крозьє підкреслює, що працівник може отримати вигоду від використання джерела невизначеності тільки за умови координації своєї поведінки з цілями організації (Крозье, 2002, с. 141).

Таким чином, джерелом невизначеності є будь-яка важка ситуація (технологічна, моральна, економічна, політична), яку лідер використовує для отримання своєї частки влади в суспільстві. Зрештою вплив на ключові суспільні джерела невизначеності приймає масштабний характер і перетворюється на силу, здатну активно протистояти офіційній владі. У результаті цих процесів у суспільстві утворюється своєрідна тіньова, паралельна влада.

Згідно із М. Крозьє (Крозье, 2005, с. 54), з одного боку, паралельна влада $\epsilon$ відхиленням від офіційного типу влади і симптомом руйнування формальних ієрархічних відносин. У цьому сенсі вона стає ознакою появи на світ нового типу влади, що відповідає вимогам демократизації і децентралізації управління, - «переговорної влади». 3 іншого боку, 
існування паралельної влади призводить до розтрати ресурсів і суспільної енергії та зрештою до «регламентаційного безумства», яке $\epsilon$ прагненням офіційної влади перекрити джерела невизначеності, в яких зароджується паралельна влада, і проявляється у постійному збільшенні випуску різних правил, указів і декретів, які стають дедалі безкорисливішими. Однак множення безособових правил не може усунути всі джерела невизначеності. В організації постійно виникають зони, навколо яких формуються нові відносини паралельної влади. Тому, на думку М. Крозьє, найбільшу значимість паралельна влада набуває саме там, де сильно розвинені бюрократичні принципи управління.

Водночас паралельна влада перетворюється на умову зміцнення бюрократичної моделі. Оскільки паралельна влада виконує функцію корекції і адаптації організаційної структури до зовнішніх трансформацій, вона забезпечує бюрократії короткостроковий динамізм.

Хоча М. Крозье і виділяє окремі позитивні риси бюрократичної системи, наприклад захист індивідів від взаємних зазіхань за допомогою бюрократичних правил, створення внутрішніх переваг для своїх членів, включаючи й тих, що перебувають на нижніх рівнях, і мінімізацію дискреційного втручання в робочі ситуації з боку начальства, тим не менше дослідник підкреслює іiї негативний вплив на розвиток організації та суспільства в цілому. Основними негативними рисами й наслідками бюрократичної моделі він вважає (Grozier, 1963; Крозье, 2002):

1) схильність до множення правил і регламентацій в організації, детально прописуючи поведінку працівників у різних ситуаціях;

2) відсутність прагнення до децентралізації влади організації та надання їй гнучкості;

3) прагнення до зміцнення ролі вищого керівництва, навіть за умови уповільнення його реакцій і втрати здатностей до більш тонкого настроювання управління;

4) надання керівникам формальної влади і соціального статусу незалежно від наслідків їх дій;

5) розширення і функціональна взаємозалежність штату заступників, помічників директорів та інших середніх начальників настільки, що це призводить до відсутності точного знання про відповідальність і принципи прийняття рішень;

6) порушення нормальних комунікаційних зв'язків між різними шаблями управлінської піраміди, що проявляється: у створенні бар'єрів i «застрягненні» директив у середніх ланках управлінської ієрархії; у відправленні нагору спотвореної інформації про результати діяльності низових рівнів;

7) виникнення так званого «світу секрету» й тенденції до монополії. Перетворення окремих шарів організаційної ієрархії на «феодальні уділи», 
які відгороджуються один від одного завдяки протекції. Усередині таких груп із метою збереження завойованого місця індивіди обмежують доступ до кола свого впливу та контакти з сусідніми ланками;

8) скутість ініціативи індивідів на нижніх щаблях ієрархії та ускладнення доступу до керівних прошарувань, що унеможливлює поступове та перманентне перетворення організаційної структури;

9) неможливість задовольняти потреби у співпраці та впровадженні інновацій шляхом експериментування.

Пошуки відповіді на питання, чому ж бюрократія розвивається, навіть при стількох негативних властивостях, привели М. Крозьє до розробки концепції замкнутого кола бюрократії (Grozier, 1963; Крозье, 2002; Крозье, 2005). За цією конщепцією бюрократизація є самопідтримуючим процесом, який являє собою порочне коло: посилення неформальних структур веде до подальшого посилення бюрократії. Саме дисфункції і зони невизначеності $€$ причиною існування, розвитку та посилення бюрократії. Тобто чим більшою мірою організація стає централізованою, чим більше вона застосовує знеособлені правила, тим активніше вона використовує ці свої якості для вирішення ними ж породжуваних проблем.

Таким чином, оригінальність підходу М. Крозьє полягає в тому, що дисфункції бюрократії він розглядає не як відхилення, а як конституючу властивість у функціонуванні сучасних бюрократичних організацій, їх латентну функцію. Виходячи з цього, він робить висновок, що бюрократична система організації - це така система, в якій дисфункції $є$ головним елементом рівноваги.

У цілому, згідно з концепцією М. Крозьє, бюрократія є соціальною системою, нездатною виправляти свої помилки. Вона не навчається $\mathrm{i}$ самостійно не адаптується до зовнішніх умов, за винятком ситуацій, що супроводжуються глобальними потрясіннями.

Незважаючи на те, що в сучасних умовах термін «бюрократія» має негативний відтінок, бюрократичні правила та процедури являють собою стандартний спосіб взаємодії. Однією із безумовних переваг цієї системи є відсутність суб'єктивізму при прийнятті і реалізації рішень, оскільки всі співробітники керуються однаковими правилами, до всіх ставляться одні й ті ж вимоги.

У середині XX ст. бюрократичні принципи побудови організацій набули максимального поширення у багатьох країнах світу. Однак надалі активне використання бюрократичних систем призвело до створення громіздких управлінських структур, які наприкінці XX - початку XXI ст. вже не відповідали умовам суспільства, особливо потребам бізнесу.

А д х о к р а т і я . Прискорення соціально-економічного і технологічного розвитку, загострення конкуренції, перехід до концепції управління на основі бізнес-процесів менше піддаються регламентації та формалізації, 
вимагають від організацій високої гнучкості й оперативності управлінської роботи. Застосування бюрократичної системи у відриві від конкретних ситуаційних характеристик без ефективної реакції організації на зміни зовнішнього та внутрішнього середовища виявилося неможливим при виконанні нових завдань. На фоні цього народився новітній, адаптивний тип організації - адхократія.

Термін «адхократія», який у прямому розумінні означає «влада, призначена для певної мети» (від лат. ad hoc - для того/призначений тільки для певної мети та грец. кро́тоৎ - влада), з'явився у середині 60-х рр. $\mathrm{XX}$ ст. Його поява пов'язана з іменем відомого американського фахівця в галузі лідерства Уорена Бенніса, який у своїй праці «Змінення організацій» передрік кончину тріумфу бюрократії і окреслив риси майбутньої організаційної структури.

На думку У. Бенніса, «тоді як захисники ідеї “добрих людських відносин" борються з бюрократією, грунтуючись на гуманістичних $\mathrm{i}$ християнських цінностях, та, своєю чергою, швидше за все сама піде на дно через нездатність адаптуватися до швидких змін...» (Bennis, 1966, p. 37). Бенніс указує на те, що бюрократія процвітає при високій стабільності, як було в період індустріалізму. Але тепер середовище змінюється так, що стабільності не стало, й тому порушується робота колись надійного бюрократичного механізму.

Проте в активний науковий обіг поняття адхократії увійшло завдяки не У. Беннісу, а американському соціологу і футурологу Елвіну Тоффрлеру, який своєю книгою «Футурошок», що вийшла в 1970 р., популяризував його. У цій філософсько-футурологічній праці він описує феномен адхократії наступним чином: «У суперіндустріальному суспільстві бюрократія буде поступово витіснятися адхократією, що координуватиме роботу безлічі тимчасових робочих груп, які виникатимуть і припинятимуть свою діяльність відповідно до темпу перемін в оточенні організації» (Тоффлер, 2002, с. 73).

Е. Тоффлер виділяє такі ознаки адхократичної організації:

1) ця організація є тимчасовою структурою;

2) вона дуже гнучка, швидко змінюється і пристосовується до оточуючого середовища;

3) увесь обсяг робіт в організації розділений на частини, які виконуються різними робочими групами;

4) роботи не стандартизовані, потребують творчого підходу до їх виконання;

5) всі співробітники повинні вміти приймати самостійні рішення i приймають їх;

6) основне завдання особи, яка керує адхократичною організацією, координування діяльності робочих груп. 
У книзі «Третя хвиля» (1980р.) Е. Тоффлер дає ще таке визначення нового типу організації: «Адхократія - це влада інтелектуалів, мобілізованих із конкретного приводу» (Тоффлер, 2010, с. 209), підкреслюючи цим, що влада в адхократії, на відміну від бюрократії, будується на авторитеті «знання», а не «стола» (!).

Е. Тоффлер розглядає адхократію як норму майбутнього, яка вже зароджується. 3 його точки зору, в світі відбуваються кардинальні зміни, які стосуються ціннісних орієнтирів людства, суспільних норм і, відповідно, організацій, що забезпечують життєдіяльність суспільства. Адхократія, на його думку, прийде на зміну організаціям із жорстким поділом праці й регламентацією діяльності, деіндивідуалізації співробітників, їх відірваності від ціннісної значимості проблем, які вирішуються організаціями.

Футурологічний прогноз Тоффлера щодо виникнення і поширення в майбутньому принципово нової форми організації, яка суперечить існуючим стереотипам і канонам управління, викликав велику хвилю інтересу як у соціологів, так і фахівців у галузі менеджменту, що вивчають проблеми розвитку постіндустріального суспільства.

Наукові ж дослідження адхократії розпочалися в 1979 р. 3 праці канадського економіста Генрі Мінцберга «Структурування організації». Це найбільш авторитетна праця з адхократії, у якій вперше вводиться визначення адхократичної організації вже з точки зору фахівця у галузі організаційних структур: «Адхократія - це високоорганічна структура 3 незначною формалізацією поведінки; вузька горизонтальна спеціалізація, що грунтується на відповідній підготовці співробітників; тенденція до об'єднання фахівців у функціональні одиниці при одночасній їх участі в невеликих проектних командах; використання інструментів взаємодії 3 метою взаємної згоди, як основного механізму координування усередині команд і між ними; вибіркова децентралізація усередині команд, які розташовуються на різних ділянках організації і включають у різній пропорції лінійних менеджерів, фахівців допоміжного персоналу й операційного ядра» (Минцберг, 2004, с. 181).

Даючи визначення адхократичної організації через перерахування всіх іiї характеристик і особливостей, Г. Мінцберг порівнює її з чотирма іншими, виділеними ним, характерними типами організаційних структур (простою структурою, механістичною і професійною бюрократіями та дивізійною формою), які широко застосовуються у практичній діяльності, й зазначає, що жоден із розглянутих типів структури не здатен на складну інноваційну діяльність у високо динамічному зовнішньому середовищі. «Організація з простою структурою, безперечно, здатна впроваджувати нововведення, але відносно нескладні. Застосування ж механістичної і професійної бюрократії орієнтоване на виконання завдань, а не вирішення проблем, на вдосконалення стандартних програм, а не на розробку нових. 
I хоча порівняно з механістичною дивізійна організація володіє підвищеною стратегічною гнучкістю, вона не $є$ справді новаторською. Концентрація на управлінні за допомогою стандартизації випуску зовсім не заохочує інноваційну діяльність (Минцберг, 2004, с. 180). На основі порівняння характеристик різних структур Г. Мінцберг робить висновок, що складні інновації вимагають абсолютно особливого дизайну організації, здатного об'єднати фахівців різних професій у злагоджено функціонуючі ad hoc (спеціальні) проектні команди.

Інноваційність організації, на думку Г. Мінцберга, означає відхід від укорінених схем і шаблонів. А це означає, що у справі координації інноваційна організація не може покладатися на бюрократичні методи. Іншими словами, вона повинна уникати всіляких бюрократичних пасток, і насамперед «капканів» жорсткого розподілу праці, диференціювання організаційних одиниць, надмірної формалізації поведінки й акцентування на системах планування і контролю. Але найголовніше - вона має бути гнучкою (Минцберг, 2004, с. 181).

3 усіх організаційних структур адхократія демонструє найменше «шанування» до класичних принципів індустріального менеджменту, i насамперед єдиноначальності. Не відіграє тут особливого значення і система регламентації. Процеси ухвалення рішень протікають неформально та гнучко, що й потрібно для новаторства. Крім того, це припускає можливість, у разі потреби, оперативного переключення владних повноважень від одного фахівця до іншого. «Адхократія повинна привертати і наділяти повноваженнями експертів - людей, які придбали знання й уміння завдяки спеціальній освіті та підготовці» (Минцберг, 2004, с. 182), які об’єднуються в багатопрофільні команди, кожна з яких формується для реалізації конкретного інноваційного проекту. Для цього адхократична організація використовує матричну структуру й одночасно функціональні та ринкові принципи групування. Висока складність праці виключає прямий контроль. Координація повинна здійснюватися компетентними співробітниками, тобто тими, хто безпосередньо зайнятий проектами, а основним механізмом координації діяльності як усередині команд, так i взаємодій між ними, на думку Мінцберга, має бути взаємне узгодження.

В адхократичній компанії, як правило, багато різних менеджерів: функціональних, відповідальних за інтеграцію діяльності, керівників проектів. Проектні команди повинні бути нечисленними, що дозволяє оперативно регулювати взаємодію їх членів. Менеджери адхократії не стільки віддають розпорядження підлеглим, скільки налагоджують взаємодії, здійснюють горизонтальну координацію діяльності команд (Минцберг, 2004, с. 183). Менеджери мають одночасно бути й фахівцями, що безпосередньо працюють над проектом разом з іншими членами команди. В адхократії ніхто не монополізує владу. 
Отже, Г. Мінцберг дає визначення адхократичної організації через перерахування всіх iï характеристик і особливостей. Насамперед він виділяє серед них взаємне узгодження дій як основний координаційний механізм, вважаючи цю характеристику адхократії найважливішою.

У цілому підходи Е. Тоффлера і Г. Мінцберга щодо визначення сутності адхократичної організації збігаються. Проте є й деякі відмінності. Мінцберг більше виділяє операційні ознаки адхократичної структури. Якщо Тоффлер розглядає адхократію як майбутню норму, то Мінцберг лише як один із типів організацій, застосування якого корисне тільки в певному випадку. У Тоффлера увага зосереджується на соціальних передумовах та наслідках поширення адхократії, Мінцберг фокусується на принципах управління, що відповідають цій організації.

Отже, можна підвести підсумок, що хоч Е. Тоффлер і Г. Мінцберг говорять однозначно про один і той самий феномен, дивляться вони на нього з різних позицій. Це й обумовлює відмінності в їх підходах та баченні перспектив.

Термін «адхократія» також використовується і для визначення типу культури організації, рамки дослідження якої задали американські дослідники Кім Камерон і Роберт Куінн у своїх працях «Життєві цикли організацій» (1983 р.) та «Діагностика і зміни організаційної культури» (1999 р.). Вони умовно виділили чотири типи культури: ієрархічну (бюрократичну), ринкову, кланову й адхократичну (Камерон \& Куинн, 2001, с. 68-79). Кожному типу, згідно з їх методологією, відповідає певний стан організації щодо стабільності, гнучкості і націленості усередину або зовні організації. Візуально все це відображено на рис. 1 та 3 деякими нашими доповненнями синтезовано у табл. 1.

К. Камерон і Р. Куінн зазначають, що в міру переходу суспільства 3 ери індустрії в еру інформації сформувався четвертий тип ідеальної організації - адхократії, яка найадекватніше реагує на надзвичайно бурхливі й мінливі зовнішні умови, якими характеризується XXI ст. Профіль або орієнтації та цінності, що визначають культурний тип цієї організації, вони описують таким чином (Камерон \& Куинн, 2001, с. 79):

1) динамічне, підприємницьке і творче місце роботи;

2) відсутність будь-якої постійної організаційної схеми;

3) тимчасовий фізичний простір;

4) люди готові підставляти власні шиї і йти на ризик;

5) люди виконують тимчасові ролі;

6) лідери вважаються новаторами, готовими ризикувати;

7) люди віддані експериментуванню та новаторству;

8) підкреслюється необхідність діяльності на передовому рубежі;

9) організація робить акцент на зростанні й отриманні нових ресурсів;

10) успіх означає виробництво унікальних і нових продуктів;

11) організація заохочує особисту ініціативу та свободу. 


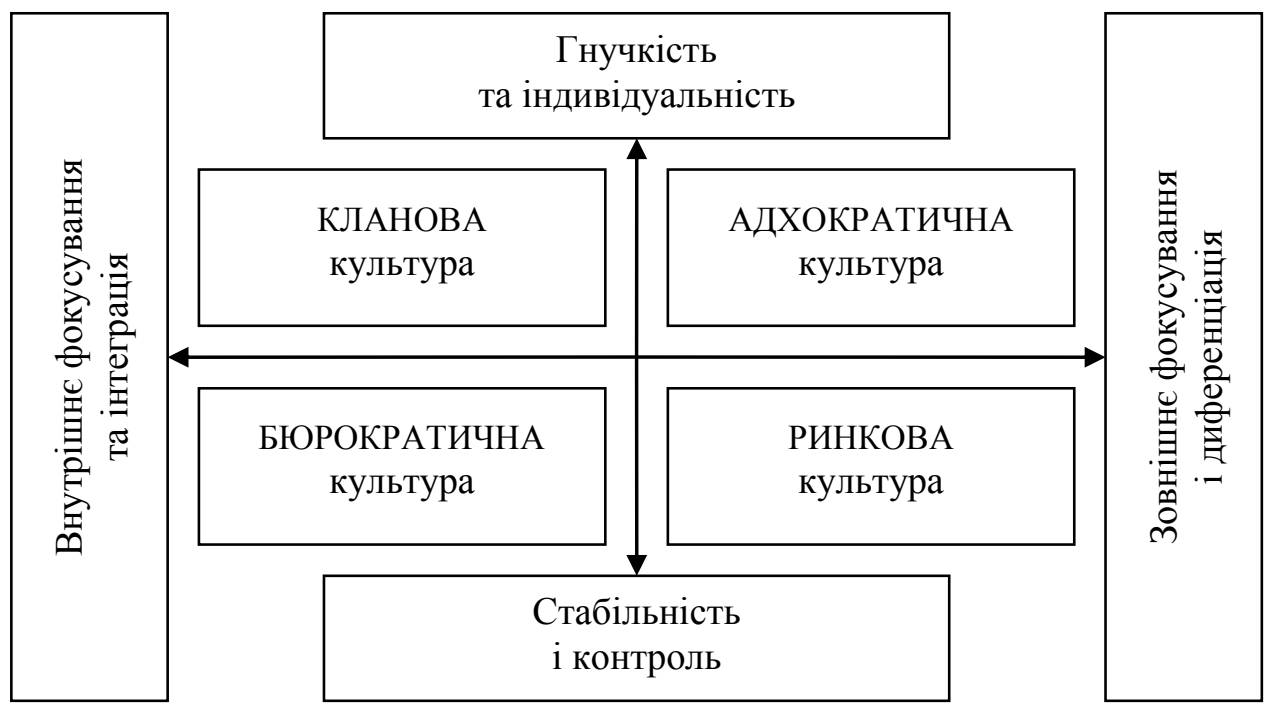

Рuc. 1. Рамкова конструкція конкуруючих цінностей різних типів культури організації Джерело: розроблено на основі (Камерон \& Куинн, 2001) Fig. 1. Scope construction of competitive values of different types of cultures of organization Source: developed on the basis of (Cameron \& Quinn, 2001)

Суттєво, що критеріями ефективності такої організації є результат на передовому рубежі, творчість, зростання, а не продуктивність, гладкість функціонування чи частка ринку, як в інших організаціях. Як зауважують К. Камерон і Р. Куінн, адхократії схожі на тимчасові структури. Вони їх характеризують як «шатра, а не палаци», тобто структури, які можна швидко реконфігурувати, як тільки виникнуть нові обставини. Головна мета адхократичної організації полягає у прискоренні адаптивності, забезпеченні гнучкості та творчого підходу до справи в ситуаціях невизначеності, двозначності та перевантаження інформацією.

3 позиції культури також суттєво, що, «на відміну від ринку або ієрархії, адхократія не використовує централізовану владу й авторитарні взаємовідносини. Влада перетікає від індивіда до індивіда або від однієї цільової бригади до іншої залежно від проблеми, яка заявляє про себе в цей момент часу» (Камерон $\&$ Куинн, 2001, с. 77). У такій організації яскраво виражений акцент на індивідуальності, заохочення ризику та передбачення майбутнього. Тут кожен працівник органічно причетний до справи, досліджень і розвитку організації. Люди виконують свої обов'язки у складі цільових бригад, які одразу розпускаються, як тільки виконано поставлене завдання. Адхократичні підрозділи можуть виникати й у достатньо великих організаціях, де домінує інший тип культури. 
Табл. 1. Профілі організаційної культури від бюрократії до адхократії Tab. 1. Types of organizational culture are from bureaucracy to adhocracy

\begin{tabular}{|c|c|c|c|c|}
\hline \multirow{2}{*}{ Показники } & \multicolumn{4}{|c|}{ Типи культури організації } \\
\hline & БЮРОКРАТІЯ & РИНОК & КЛАН & АДХОКРАТІЯ \\
\hline $\begin{array}{l}\text { Середовище } \\
\text { організації }\end{array}$ & $\begin{array}{l}\text { Мало- } \\
\text { конкурентне }\end{array}$ & Конкурентне & Конкурентне & $\begin{array}{l}\text { Гіпер- } \\
\text { конкурентне }\end{array}$ \\
\hline Зміни & Повільні & Швидкі & Швидкі & Надшвидкі \\
\hline Невизначеність & Незначна & Значна & Значна & Майже повна \\
\hline $\begin{array}{l}\text { Фокус уваги } \\
\text { організації }\end{array}$ & $\begin{array}{l}\text { Внутрішня } \\
\text { підтримка } \\
\text { в поєднанні } \\
\text { з необхідною } \\
\text { стабільністю } \\
\text { і контролем }\end{array}$ & $\begin{array}{l}\text { Зовнішні } \\
\text { позиції } \\
\text { в поєднанні } \\
\text { з необхідною } \\
\text { стабільністю } \\
\text { та контролем }\end{array}$ & $\begin{array}{l}\text { Внутрішня } \\
\text { підтримка } \\
\text { гнучкості, } \\
\text { турбота про } \\
\text { людей і добре } \\
\text { почуття до } \\
\text { споживачів }\end{array}$ & $\begin{array}{l}\text { Зовнішні } \\
\text { позиції } \\
\text { в поєднанні } \\
\text { з високою } \\
\text { гнучкістю та } \\
\text { індивідуальні- } \\
\text { стю підходів }\end{array}$ \\
\hline Місце роботи & $\begin{array}{l}\text { Формалізоване } \\
\text { і структуроване }\end{array}$ & $\begin{array}{l}\text { Орієнтоване } \\
\text { на результати }\end{array}$ & $\begin{array}{l}\text { Дуже дружнє, } \\
\text { схоже на сім’ю }\end{array}$ & $\begin{array}{l}\text { Динамічне } \\
\text { і творче }\end{array}$ \\
\hline $\begin{array}{l}\text { Критерії } \\
\text { ефективності }\end{array}$ & $\begin{array}{l}\text { Рентабельність, } \\
\text { своєчасність, } \\
\text { гладке функ- } \\
\text { ціонування } \\
\text { організації }\end{array}$ & $\begin{array}{l}\text { Ринкова частка, } \\
\text { проникнення } \\
\text { на нові ринки, } \\
\text { поразка кон- } \\
\text { курентів }\end{array}$ & $\begin{array}{l}\text { Згуртованість, } \\
\text { моральний } \\
\text { клімат, розви- } \\
\text { ток людських } \\
\text { ресурсів }\end{array}$ & $\begin{array}{l}\text { Результат } \\
\text { на передовому } \\
\text { рубежі, } \\
\text { творчість, } \\
\text { зростання }\end{array}$ \\
\hline Тип лідера & $\begin{array}{l}\text { Інструктор, } \\
\text { координатор }\end{array}$ & $\begin{array}{l}\text { Боєць, поста- } \\
\text { новник проблем }\end{array}$ & $\begin{array}{l}\text { Наставник, } \\
\text { батько }\end{array}$ & $\begin{array}{l}\text { Новатор, } \\
\text { провидець }\end{array}$ \\
\hline HR-роль & $\begin{array}{l}\text { Фахівець- } \\
\text { адміністратор }\end{array}$ & $\begin{array}{l}\text { Стратегічний } \\
\text { бізнес-партнер }\end{array}$ & $\begin{array}{l}\text { Захисник } \\
\text { працівників }\end{array}$ & $\begin{array}{l}\text { Агент зі змін } \\
\text { (перетворень) }\end{array}$ \\
\hline $\begin{array}{l}\text { Концепція } \\
\text { менеджменту }\end{array}$ & $\begin{array}{l}\text { Контроль } \\
\text { сприяє рента- } \\
\text { бельності }\end{array}$ & $\begin{array}{l}\text { Конкуренція } \\
\text { сприяє ефек- } \\
\text { тивності }\end{array}$ & $\begin{array}{l}\text { Співчуття } \\
\text { укріплює } \\
\text { відданість }\end{array}$ & $\begin{array}{l}\text { Новаторство } \\
\text { виношує нові } \\
\text { ресурси }\end{array}$ \\
\hline $\begin{array}{l}\text { Основне } \\
\text { завдання } \\
\text { менеджменту }\end{array}$ & $\begin{array}{l}\text { Контролювати } \\
\text { процеси, } \\
\text { виявляти й } \\
\text { усувати } \\
\text { помилки } \\
\end{array}$ & $\begin{array}{l}\text { Задовольняти } \\
\text { вподобання } \\
\text { споживачів } \\
\text { і перемагати } \\
\text { конкурентів } \\
\end{array}$ & $\begin{array}{l}\text { Наділяти } \\
\text { працівників } \\
\text { повноважен- } \\
\text { нями й залу- } \\
\text { чати до бізнесу }\end{array}$ & $\begin{array}{l}\text { Дивувати } \\
\text { унікальними } \\
\text { продуктами й } \\
\text { заохочувати } \\
\text { самоорганізацію }\end{array}$ \\
\hline $\begin{array}{l}\text { Структура } \\
\text { управління }\end{array}$ & $\begin{array}{l}\text { Повністю } \\
\text { централізована, } \\
\text { вертикальна, } \\
\text { дуже жорстка }\end{array}$ & $\begin{array}{l}\text { Частково де- } \\
\text { централізована, } \\
\text { горизонтально- } \\
\text { вертикальна }\end{array}$ & $\begin{array}{l}\text { Частково } \\
\text { централізована, } \\
\text { вертикально- } \\
\text { горизонтальна }\end{array}$ & $\begin{array}{l}\text { Повністю де- } \\
\text { централізована, } \\
\text { горизонтальна, } \\
\text { надпластична }\end{array}$ \\
\hline $\begin{array}{l}\text { Механізм } \\
\text { управління }\end{array}$ & $\begin{array}{l}\text { Бюрократичні } \\
\text { правила і } \\
\text { процедури }\end{array}$ & $\begin{array}{l}\text { Ринкова кон- } \\
\text { куренція та } \\
\text { цінові сигнали }\end{array}$ & $\begin{array}{l}\text { Наставництво } \\
\text { щодо персоналу } \\
\text { та ціннісні } \\
\text { сигнали } \\
\end{array}$ & $\begin{array}{l}\text { Колективне } \\
\text { самовряду- } \\
\text { вання та } \\
\text { колаборація }\end{array}$ \\
\hline
\end{tabular}

Джерело: розроблено на основі (Камерон \& Куинн, 2001; Мартинишин \& Коваленко, 2018а) Source: developed on the basis of (Cameron \& Quinn, 2001; Martynyshyn \& Kovalenko, 2018a) 
Сьогодні в умовах різкого зростання невизначеності й динамізму середовища, збільшеного тиску швидкостей і потоків інформації на умови життєдіяльності людей роль і значення адхократичних організацій, а також організацій іншого типу (бюрократичних, ринкових, кланових), але з елементами адхократії, істотно зростає. А жорстко централізовані структури витісняються як такі, що не справляються з цим середовищем.

Бюрократичний механізм управління був розрахований на стабільність. Потім із зростанням динамізму й невизначеності з'явився ринковий механізм. У суперіндустріальну еру, при наддинамічному середовищі, 3'являється адхократичний механізм, який дозволяє діяти в умовах відкритих ринків та глобальної конкуренції.

На макрорівні йдеться про об'єктивну тенденцію до соціалізації системи управління. У передових країнах спостерігається зародження нової, горизонтальної, адхократичної культури соціальних взаємодій, коли усі інституціональні гравці прагнуть відійти від субординації. Це розмиває бюрократії зсередини - веде до принципової зміни статусу i положення в структурі влади. Традиційна модель управління, що грунтується на єдиноначальності, відходить у минуле.

Провідний американський теоретик менеджменту Пітер Друкер у своїй книзі «Управління в суспільстві майбутнього» (2002р.) цікаво формулює питання взаємозв'язку адхократії з інноваційним розвитком. Налаштовані на оновлення його нові організації реалізують шумпетерівську ідею творчого руйнування: вони безперервно збуджуватимуть суспільство, спонукаючи його відмовлятися від усього укоріненого раніше і тим самим рухатися вперед, постійно пред’являючи попит на нові знання. Він також підкреслює, що ці організації повинні працювати на принципах команди з рівноправними учасниками (поза субординацією), і посилається на вражаючі успіхи японських компаній, де принцип командної роботи був освоєний ще в індустріальну епоху. Говорячи про значущість адхократичної організаційної структури, він також роздумує про можливість iї застосування у державному управлінні, що приведе до створення нового суспільства, де соціальний консенсус досягатиметься у формі не політичного, а управлінського плюралізму (Друкер, 2007).

Проте сьогодні, вже навіть у другому десятилітті XXI ст., ми не спостерігаємо краху бюрократичних структур, який провіщали Е. Тоффлер та його послідовники. Звичайно, конструювання майбутнього - справа невдячна для вченого, якого можуть звинуватити в занятті белетристикою, а нащадки, зайнявши позицію навчених часом критиків, знайдуть багато наївного в описах майбутнього, запропонованих своїм попередником. Ми ні в якому разі не намагаємося цього робити, адже багато інших прогнозів Тоффлера все-таки, тією чи іншою мірою, збуваються. 
Комп’ютеризація і автоматизація управління, на думку Е. Тоффлера, мала стати тим чинником, який зіграє не останню роль у руйнуванні класичної бюрократії. Бюрократія орієнтована на ухвалення рутинних рішень із рутинних питань. Постійні зміни створюють неординарні проблеми, що вимагають неординарних рішень, тому бюрократія стає безсилою в цих умовах. Рутину, як вважав Тоффлер, мають взяти на себе комп'ютери.

Що ж відбулося сьогодні, коли комп’ютери і кібермережі стали невід'ємною частиною інтер'єру будь-якої організації? Очевидно, що, істотно спрощуючи документообіг і розширюючи можливості інформаційного обміну, сучасні електронні «друзі людини» грають на руку бюрократії.

По-перше, документ завдяки розвитку розмножувальної техніки став набувати ще більшого символічного значення, зайнявши положення валового результату офісного виробництва. Отже, комп'ютеризація принесла 3 собою не очікуване скорочення документообігу на паперових носіях, а його збільшення. Тепер замість одного-двох машинописних екземплярів можна за кілька хвилин отримати сотню або дві чудово оформлених бюрократичних продуктів. I все це можна розмістити по архівах, папках і роздати в паралельні відділи. При цьому, зрозуміло, обов'язково зберегти все в електронному варіанті. Чи не $є$ це раєм для бюрократії, робота якої заснована на створенні та підтримці документообігу?

По-друге, контроль завжди вважався однією з центральних функцій бюрократії та управління. Тепер можна здійснювати тотальний контроль за кожним службовцем і взагалі громадянином завдяки поширенню все тих же електронних мереж. Спочатку в США, а тепер й у нас кожному громадянинові присвоюють ідентифікаційний код і створюють для кожного комірчину в глобальних базах даних, де відображаються будь-які зміни в доходах, статусі, місці мешкання, сімейному стані. Якщо людина не занесена в базу даних, то вона перестає існувати для держави, для медичних установ, стає такою, яка не існує для бюрократії. А подивіться, як глибоко і масштабно ідентифікується наукова діяльність: ORCID ID вченого, DOI наукової статті, ISSN наукового журналу, ISBN наукової монографії, підручника, навчального посібника тощо! Сформувався цілий клас наукової бюрократії.

У рамках окремих організацій практика тотального контролю також набуває рутинного характеру: нині менеджер може спостерігати за своїми підлеглими за допомогою відеокамер, електронна система контролює час, у який співробітники залишають робочі місця, комп'ютерні програми дозволяють відстежувати те, що в будь-який момент висвічується на екрані комп'ютера кожного співробітника, - тобто класичні веберівські бюрократи тільки могли мріяти про такі можливості для контролю. Епоха «гвинтиків великої машини» не минула, на розчарування багатьох. 
По-третє, очевидно, що в реальній практиці управління будь-який комп'ютер не може ухвалити «правильного» рішення - останне слово завжди залишається за людиною. Тільки вона може врахувати найнепередбачуваний чинник - людський.

Отже, підсумковим може бути висновок, що комп'ютеризація грає на руку бюрократії, яка міняється, але стає більш безсмертною сьогодні, ніж була вчора.

Стосовно адхократії як форми устрою організацій майбутнього, то тут ще більше питань, ніж відповідей. Насамперед, чи зможе така організація існувати у чистому вигляді й поза межами хоча б елементарної ієрархії. На нашу думку, очевидно ні, оскільки вона втратить цілісність. Адже, як відомо, основою збереження цілісності будь-якої організації в суспільстві та природі є саме ієрархія. Суцільна відсутність ієрархії означає розпад організації. Крім того, треба не забувати, що критерієм істини або правильності тієї чи іншої теорії є суспільна практика. І якщо теорія використовується на практиці - це означає, що вона правильна, а якщо ні, то неправильна. На сьогоднішній день використання теорії чистої адхократії на практиці не спостерігається, за винятком експериментів, які проводяться у каліфорнійській Силіконовій долині, та ще кількох. Отже, можна зробити висновок, що висловлювання вчених щодо ідеальної адхократичної організації поки що є тільки припущенням того, що ймовірно буде в майбутньому. Водночас, слід особливо зазначити, що практикою сьогодні вже доведено достовірність теоретичних тверджень стосовно ефективності використання ідеальних адхократичних підрозділів (робочих груп) у складі організацій (табл. 2).

Табл. 2. Поєднання структур у конгломератних організаціях бізнесу Tab. 2. Combination of structures in organizations of conglomerates business

\begin{tabular}{|l|c|c|c|}
\hline \multirow{2}{*}{ Види структур } & \multicolumn{3}{|c|}{ Варіанти поєднання структур } \\
\cline { 2 - 4 } & I & II & III \\
\hline \multicolumn{3}{|c|}{ Конгломерат європейської культури бізнесу } \\
\hline Бюрократія & + & + & + \\
\hline Ринок & + & + & + \\
\hline Адхократія & \multicolumn{3}{|}{+} \\
\hline \multicolumn{3}{|c|}{ Конгломерат азіатської культури бізнесу } \\
\hline Клан & + & + & + \\
\hline Ринок & + & + & + \\
\hline Адхократія & & + & + \\
\hline
\end{tabular}

Джерело: власна розробка

Source: own development 
3 огляду на це, у нашому розумінні організація майбутнього - це скоріше структура конгломератного типу, що є поєднанням кількох ідеальних типів організаційних структур, залежно від призначення організації й умов зовнішнього оточення. Так, очевидно, у сфері держуправління буде переважати бюрократичний тип. А щодо управління бізнесом, то тут навпаки - організація включатиме як основу збереження цілісності та стійкості «легкий» вертикальний ієрархічний каркас (бюрократію 3 незначною формалізацією) і набір горизонтальних децентралізованих «важковагових» ринкових й адхократичних внутрішніх структур, глибоко занурених у зовнішне середовище. В азіатському бізнесі у цій комбінації місце бюрократії посяде клан. Рівень органічності системи-організації зростатиме у міру переходу від першого до третього варіантів поєднання організаційних структур.

Головним достоїнством й основним призначенням автономних адхократичних структур усередині бізнесових організацій $€$ їх здатність швидко і гнучко відповідати на гіперконкурентні, складні та швидкомінливі зовнішні виклики. Однак все це можливо лише за наявності високого рівня професійної компетентності, підприємливості та відповідальності персоналу бізнесових організацій.

\section{4. Висновки та обговорення результатів Conclusions and discussion of results}

У статті наведено аналіз еволюції теорії менеджменту в контексті історичного розвитку організацій від бюрократії до адхократії, однієї із центральних проблем суспільної думки, що постійно перебуває у центрі їі уваги впродовж останніх двох століть. Результати дослідження дозволяють дійти таких висновків:

1. Бюрократія виникла з появою письма у Стародавньому Єгипті (IV тис. до н. е.), звідки у процесі історичного розвитку в поєднанні з іншими типами структур поширилася на весь цивілізований світ, сформувавшись в основну форму організації життєдіяльності суспільства.

2. Наукове осмислення феномену бюрократії й домінування іiї як основної форми організації життєдіяльності суспільства розпочалося в епоху підйому індустріалізму, виникнення європейської раціональної науки та появи ньютонівської механістичної картини світу (XVIII ст.).

3. Дослідження бюрократії оформилося у два напрями. Засновниками першого (XIX ст.) - політичного - $\epsilon$ Г. Гегель, який у бюрократичному устрої держави бачив ідеал улаштування суспільства, і К. Маркс, який вважав це злом, що виражається у відчуженні влади від суспільства. 
4. Засновником другого - соціологічного - напряму вважається М. Вебер (поч. XX ст.), який продемонстрував достоїнство бюрократії як технічно найефективнішої системи, що відповідає стадії машинного виробництва і грунтується на раціональному, безособовому управлінні, використанні формальних засобів, які не схильні до суб'єктивізму керівника та впливу традицій.

5. Існування бюрократії передбачає наявність стабільного середовища, жорсткої ієрархії, раціональних структур і індивідів, які беззаперечно виконують розпорядження й відповідають запропонованим їм ролям. Жодні відступи від формально встановлених процедур і правил неприпустимі.

6. У середині XX ст. бюрократичні принципи побудови організацій набули максимального поширення, проте внаслідок ускладнення суспільних відносин стали проявлятися деякі їх недоліки, з дослідженням яких пов'язана поява різноманітних концепцій бюрократії.

7. Р. Мертон довів, що, незважаючи на ряд позитивних досягнень, бюрократична організація все більше проявляє свою недосконалість у вигляді дисфункцій, відсутності гнучкості й здатності пристосовуватися до ситуації, наявністю формалізму, ритуалізму та бюрократичної тяганини.

8. Е. Гоулднер встановив, що зміна бюрократії відбувається паралельно 3 розвитком суспільства й еволюціонує від авторитарної (репресивної), заснованої на вимозі сліпого виконання правил, до представницької (експертної), яка спирається на знання і переконання.

9. Е. Доунс розробив концепцію життєвого циклу бюрократії і показав його вплив на управлінську діяльність. Виявив закон консерватизму, згідно з яким всі організації з віком стають консервативнішими, якщо не перебувають на стадії зростання або внутрішньої реорганізації.

10. М. Крозьє дослідив, що причиною дисфункцій бюрократії є зони, в яких обмежені можливості формальної влади. Залежно від значимості невизначеності, контрольованої певним актором, зростає його влада в організації. У результаті виникає неформальна влада, яка веде до посилення формальної влади й бюрократії в цілому.

11. У 70-х pp. ХХ ст. стабільність різко порушилася, і бюрократія виявилася нездатною до існування в динамічному бізнес-середовищі. Відбувся відступ від жорсткої ієрархії і перехід до ринкового та інших типів частково децентралізованих структур, механізмом функціонування яких були вже не правила, а цінові та інші сигнали зовнішнього оточення.

12. У цей час також зародився абсолютно новий, адаптивний тип організації - адхократія, популяризатором якої був Е. Тоффлер. Він означував іiї як владу інтелектуалів, підкреслюючи цим, що влада в адхократії, на відміну від бюрократії, будується на авторитеті «знання», а не «стола». 
13. Дослідження адхократії розпочалися у 1980-х рp. із праць Г. Мінцберга, який охарактеризував ії як високоорганічну структуру 3 функціональними й ринковими принципами групування фахівців у проектні команди з незначною формалізацією і взаємоузгодженням дій як механізмом координування.

14. Процеси ухвалення рішень в адхократії протікають неформально. Виключається прямий контроль. Менеджери мають одночасно бути фахівцями, які безпосередньо працюють над проектом. В адхократії ніхто не монополізує владу. Вона найбільше здатна на інноваційну діяльність.

15. У 1990-х рр. К. Камерон і Р. Куінн встановили, що в еру інформації найідеальнішим типом організаційної культури буде адхократія. Критерієм ії ефективності є результат на передовому рубежі, а головна мета - прискорення адаптивності, забезпечення гнучкості та творчого підходу до справи в ситуаціях невизначеності й перевантаження інформацією.

16. На початку XXI ст. П. Друкер довів, що налаштовані на безперервні оновлення адхократії реалізуватимуть шумпетерівську ідею творчого руйнування, безперервно збуджуючи і спонукаючи суспільство відмовлятися від усього укоріненого раніше і тим самим рухатися вперед.

17. Однак у XXI ст. не відбулося краху бюрократії, який провіщав Тоффлер, а, навпаки, спостерігається ії посилення на основі комп’ютерних засобів тотального контролю, про який веберівські бюрократи могли тільки мріяти. Бюрократія змінюється, але стає ще більш безсмертною.

18. Адхократія не зможе існувати в чистому вигляді поза межами ієрархії. Організація майбутнього - це структура конгломератного типу, що включає як основу збереження цілісності «легкий» ієрархічний каркас та набір децентралізованих ринкових й адхократичних груп, занурених у зовнішнє середовище.

Наукова новизна одержаних результатів полягає в уточненні окремих положень теорії менеджменту щодо прогнозування тенденцій і перспектив розвитку бюрократичних й адхократичних структур у суперіндустріальному суспільстві. Зокрема, спростовано припущення про крах бюрократій та процвітання адхократій в умовах нового суспільства і доведено можливість поширення у цих умовах конгломератного типу організацій, що поєднують бюрократичну (кланову), ринкову й адхократичну структури.

Практичне значення одержаних результатів виявляється у можливості використання їх для розробки методичних рекомендацій із проектування адаптивних організацій в умовах глобалізації світу.

Перспективами подальших наукових розвідок у цьому напрямі може бути розроблення механізмів управління конгломератних організацій. 


\section{Література}

Батрименко О. В. Тенденції розвитку бюрократії в умовах сучасного суспільнополітичного життя. Вісник Київського наиіонального університету ім. Тараса Шевченка. Філологія. Політологія. 2009. № 91/93. С. 188-191.

Блюмкин В. А. Бюрократизм: социально-нравственные аспекты. Москва : Знание, 1987. 164 с.

Боднарук В. Д. Бюрократизм як феномен раціональної бюрократії. Аспекти публічного управління. 2016. № 3 (29). С. 29-37.

Вебер М. Хозяйство и общество. Пер. с нем. Москва : Высшая школа экономики, 2010. $456 \mathrm{c}$.

Гайденко П. П., Давыдов Ю. Н. История и рациональность. Социология М. Вебера и веберовский ренессанс. Москва : Политиздат, 1991. 367 с.

Гегель Г. В. Ф. Философия права. Пер. с нем. Москва : Мысль, 1990. 524 с.

Графский В. Г. Государство и технократия. Москва : Прогресс, 1981. 276 с.

Друкер П. Управление в обществе будущего. Пер. с англ. Москва : Вильямс, 2007. $320 \mathrm{c}$.

Камерон К., Куинн Р. Диагностика и изменение организационной культуры. Пер. с англ. Санкт-Петербург : Питер, 2001. 320 с.

Коваленко С. Я. Культура менеджменту Стародавнього світу та Середньовіччя. Біла Церква : Вид. Пшонківський О. В., 2017. 230 с.

Крозье М. Актеры и системы. Пер. с фр. Санкт-Петербург : Питер, 2002. $308 \mathrm{c}$.

Крозье М. Беспокойство об Америке. Пер. с фр. Москва : АСТ, 2005. 276 с.

Макаренко В. П. Теория бюрократии М. Вебера и буржуазные концепции организации и управления. Bопросы философии. 1985. № 3. С. 14-21.

Маркс К. К критике гегелевской философии права. К. Маркс, Ф. Энгельс. Сочинения: в 50 т. Москва: Политиздат, 1974. Т. 1. С. 219-368.

Мартинишин Я. М., Коваленко Є. Я. Формування сучасної системи управління життедіяльністю суспільства. Вісник Київського наиіонального університету культури і мистеитв. Серія: Менеджмент соиіокультурної діяльності. 2018. Вип. 1. С. 7-24.

Мартинишин Я. М. Мистецтво управління й освітні технології підготовки менеджерів соціокультурної діяльності. Біла Церква : Вид. Пшонківський О. В., 2018. 374 с.

Масловский М. В. Теория бюрократии Макса Вебера и современная социология. Нижний Новгород : НГУ, 1997. 187 с.

Мертон Р. Бюрократическая структура и личность. Сочиальная теория $u$ соииальная структура. Пер. с англ. Москва : АСТ, 2006. С. 323-337.

Минцберг Г. Структура в кулаке. Пер. с англ. Санкт-Петербург : Питер, 2004. $512 \mathrm{c}$.

Оболонский А. В. Бюрократия и государство. Москва : Институт государства и права РАН, 1996. 170 с.

Оболонский А. В. Кризис бюрократического государства. Москва : Либеральная миссия, 2011. 448 с.

Ожиганов Э. Н. Политическая теория Макса Вебера. Рига : Зинате, 1986. $288 \mathrm{c}$. 
Паєтко Т., Федосов В. Українська бюрократія: концептуальні засади і особливості функціонування. Ринок цінних паперів Украӥни. 2016. № 9-10. C. 3-16.

Попов С. И. Политика, экономика, мораль. Москва : Мысль, 1989. 308 с.

Рудинський Ф. М. Бюрократизм і проблеми його викорінення. Сучасна держава і право. 1994. № 5. С. 35-40.

Тоффлер Э. Третья волна. Пер. с англ. Москва : АСТ, 2010.784 с.

Тоффлер Э. Шок будущего. Пер. с англ. Москва : АСТ, 2002. 557 с.

Туленков М. В. Концептуалізація дисфункцій сучасної бюрократії. Ринок праиі та зайнятість населення. 2011. № 3. С. 51-53.

Тюрго А. Похвальное слово Венсану де Гурнэ. Избранные экономические произведения. Пер. с фр. Москва : Директ-Медиа, 2010. С. 169-187.

Хасбулатов Р. И. «Бюрократия тоже наш враг...». Социализм и бюрократия. Москва : Политиздат, 1989. 334 с.

Хасбулатов Р. И. Бюрократическое государство. Москва : Мегаполис, $1991.255 \mathrm{c}$.

Худокормов А. Г. Экономические корни бюрократизма. Москва : Экономика, $1988.96 \mathrm{c}$.

Цапко О. Наукові теорії про місце бюрократії в сучасному суспільстві. Філософські та методологічні проблеми права. 2012. № 2. С. 20-24.

Яковенко Г. Б. Функції сучасної державної бюрократії. Теорія та практика державного управління. 2008. № 3 (22). С. 51-58.

Bennis W. Changing Organizations. New York : McGraw-Hill, 1966. 268 p.

Downs A. Inside Bureaucracy. Boston : Little, Brown, Inc., 1967. 292 p.

Gouldner A. Patterns of Industrial Bureaucracy. Glencoe : The Free Press, 1954. $282 \mathrm{p}$.

Grozier M. Le Phenomene bureaucratique. Paris : Ed. du Seuil, 1963. 234 p.

Стаття надійшла до редакції 14.07.2018

\section{References}

Batrymenko, O. V. (2009). Tendentsii rozvytku biurokratii v umovakh suchasnoho suspil'no-politychnoho zhyttia [Trends in the development of bureaucracy in modern political life]. Visnyk Kyivs'koho natsional'noho universytetu imeni Tarasa Shevchenka. Filolohiia. Politolohiia [Herald of Kyiv national University named after Taras Shevchenko. Philology. Political], 91/93, 188-191 (in Ukr.).

Bennis, W. (1966). Changing Organizations. New York: McGraw-Hill.

Bliumkin, V. A. (1987). Biurokratizm: sotsial'no-nravstvennye aspekty [Bureaucracy: a socio-ethical aspects]. Moscow: Znanie (in Russ.).

Bodnaruk, V. D. (2016). Biurokratyzm iak fenomen ratsional'noi biurokratii [The phenomenon of Bureaucracy as a rational bureaucracy]. Aspekty publichnoho upravlinnia [Aspects of public administration], 3 (29), 29-37 (in Ukr.). 
Cameron, K., \& Quinn, P. (2001). Diagnostika i izmenenie organizatsionnoi kul'tury [Diagnosing and Changing Organizational Culture]. (Trans. in Eng.). St. Petersburg: Piter (in Russ.).

Downs, A. (1967). Inside Bureaucracy. Boston: Little, Brown, Inc.

Drucker, P. (2007). Upravlenie v obshchestve budushchego [Managing in the Next Society]. (Trans. in Eng.). Moscow: Vil'iams (in Russ.).

Gaidenko, P. P., \& Davydov, I. N. (1991). Istoriia i ratsional'nost'. Sotsiologiia $M$. Webera i veberovskii renessans [History and rationality. Sociology of M. Weber and Weber's Renaissance]. Moscow: Politizdat (in Russ.).

Gouldner, A. (1964). Patterns of Industrial Bureaucracy. Glencoe: The Free Press.

Grafskii, V. G. (1981). Gosudarstvo i tekhnokratiia [State and technocracy]. Moscow: Progress (in Russ.).

Grozier, M. (1963). Le Phenomene bureaucratique [The Phenomenon of Bureaucracy]. Paris: Ed. du Seuil (in Fr.).

Grozier, M. (2002). Aktory i sistemy [Actors and Systems]. (Trans. in Fr.). St. Petersburg: Piter (in Russ.).

Grozier, M. (2005). Bespokoistvo ob Amerike [Anxiety about America]. (Trans. in Fr.). Moscow: Piter (in Russ.).

Hegel, G. W. F. (1990). Filosofiia prava [Philosophy of law]. (Trans. in Germ.). Moscow: Mysl' (in Russ.).

Khasbulatov, R. I. (1989). «Biurokratiia tozhe nash vrag...». Sotsializm i biurokratiia ["Bureaucracy is our enemy...". Socialism and bureaucracy]. Moscow: Politizdat (in Russ.).

Khasbulatov, R. I. (1991). Biurokraticheskoe gosudarstvo [Bureaucratic state]. Moscow: Megapolis (in Russ.).

Khudokormov, A. G. (1988). Ekonomicheskie korni biurokratizma [Economic roots of bureaucracy]. Moscow: Ekonomika (in Russ.).

Kovalenko, Y. Y. (2017). Kul'tura menedzhmentu Starodavn'oho svitu ta Seredn'ovichchia [Management Culture of the Ancient world and the Middle Ages]. Bila Tserkva: Vydavets O. V. Pshonkivskyj (in Ukr.).

Makarenko, V. P. (1985). Teoriia biurokratii M. Webera i burzhuaznye kontseptsii organizatsii i upravleniia [Theory of bureaucracy of M. Weber and bourgeois concepts of organization and management]. Voprosy filosofii [The problems of philosophy], 3, 14-21 (in Russ.).

Martynyshyn, Y. M., \& Kovalenko, Y. Y. (2018a). Formuvannia suchasnoi systemy upravlinnia zhyttiediial'nistiu suspil'stva [Formation of the modern system management of life society]. Visnyk Kyivs'koho natsional'noho universytetu kul'tury i mystetstv. Seriia: Menedzhment sotsiokul'turnoi diial'nosti [Bulletin of Kyiv National University of Culture and Arts. Series in Management of social and cultural activity], 1, 7-24 (in Ukr.).

Martynyshyn, Y. M. (2018b). Mystetstvo upravlinnia j osvitni tekhnolohii pidhotovky menedzheriv sotsiokul'turnoi diial'nosti [Art of management and educational technologies of preparation of managers of of social and cultural activity]. Bila Tserkva: Vydavets O. V. Pshonkivskyj (in Ukr.).

Marx, K. (1974). K kritike gegelevskoi filosofii prava [Critique of Hegel philosophy of law]. K. Marx, F. Engels. Sochineniia [K. Marx, F. Engels. Composition] (Vol. 1). Moscow: Politizdat (in Russ.). 
Maslovskii, M. V. (1997). Teoriia biurokratii Maksa Webera i sovremennaia sotsiologiia [Theory of bureaucracy Max Weber and modern sociology]. Nizhnii Novgorod: NGU (in Russ.).

Merton, R. (2006). Biurokraticheskaia struktura i lichnost' [Bureaucratic structure and personality]. Sotsial'naia teoriia i sotsial'naia struktura [Social Theory and Social Structure]. (Trans. in Eng.). Moscow: AST, 323-337 (in Russ.).

Mintzberg, H. (2004). Struktura v kulake [Structure in Fives]. (Trans. in Eng.). St. Petersburg: Piter (in Russ.).

Obolonskii, A. V. (1996). Biurokratiia i gosudarstvo [Bureaucracy and the state]. Moscow: Institut gosudarstva i prava RAN (in Russ.).

Obolonskii, A. V. (2011). Krizis biurokraticheskogo gosudarstva [Crisis of the bureaucratic state]. Moscow: Liberal'naia missiia (in Russ.).

Ozhiganov, E. N. (1986). Politicheskaia teoriia Maksa Vebera [The political theory of max Weber]. Riga: Zinate (in Russ.).

Paietko, T., \& Fedosov, V. (2016). Ukrains'ka biurokratiia: kontseptual'ni zasady i osoblyvosti funktsionuvannia [Ukrainian bureaucracy: conceptual foundations and specific features of functioning]. Rynok tsinnykh paperiv Ukrainy [The securities market of Ukraine], 9-10, 3-16 (in Ukr.).

Popov, S. I. (1989). Politika, ekonomika, moral' [Politics, economics, morality]. Moscow: Mysl' (in Russ.).

Rudyns'kyj, F. M. (1994). Biurokratyzm i problemy joho vykorinennia [Bureaucracy and the problem of its eradication]. Suchasna derzhava i pravo [Modern state and law], 5, 35-40 (in Ukr.).

Toffler, A. (2002). Shok budushchego [Future Shock]. (Trans. in Eng.). Moscow: AST (in Russ.).

Toffler, A. (2010). Tret'ia volna [The Third Wave]. (Trans. in Eng.). Moscow: AST (in Russ.).

Tsapko, O. (2012). Naukovi teorii pro mistse biurokratii v suchasnomu suspil'stvi [Scientific theories about the place of bureaucracy in modern society]. Filosofs'ki ta metodolohichni problemy prava [Philosophical and methodological problems of law], 2, 20-24 (in Ukr.).

Tulenkov, M. V. (2011). Kontseptualizatsiia dysfunktsij suchasnoi biurokratii [Conceptualization of the dysfunctions of modern bureaucracy]. Rynok pratsi ta zajniatist' naselennia [Labour market and employment], 3, 51-53 (in Ukr.).

Turgot, A. (2010). Pokhval'noe slovo Vensanu de Gurne [Eulogy to Vincent de Gournay railway station]. Izbrannye ekonomicheskie proizvedeniia [Selected economic work]. (Trans. in Fr.). Moscow: Direkt-Media, 169-187 (in Russ.).

Weber, M. (2010). Khoziaistvo i obshchestvo [Economy and society]. (Trans. in Germ.). Moscow: Vysshaia shkola ekonomiki (in Russ.).

Yakovenko, H. B. (2008). Funktsii suchasnoi derzhavnoi biurokratii [The functions of a modern state bureaucracy]. Teoriia ta praktyka derzhavnoho upravlinnia [Theory and practice of public administration], 3 (22), 51-58 (in Ukr.).

Received 14.07.2018 